\title{
Monetary Policy and Financial Stability in the Nigerian Banking Industry
}

\author{
Oparah Felix Chukwudi ${ }^{1} \&$ James Tumba Henry ${ }^{2}$ \\ 1 Department of Economics, Faculty of Social Sciences, University of Calabar, Calabar, Nigeria \\ 2 Department of Economics, Faculty of Social and Management Sciences, Adamawa State University, Mubi, Nigeria \\ Correspondence: James Tumba Henry, Department of Economics, Faculty of Social and Management Sciences, \\ Adamawa State University, Mubi, Nigeria.
}

Received: September 3, 2019

Accepted: October 11, 2019

Online Published: October 21, 2019

doi:10.5430/ijfr.v11n1p82

URL: https://doi.org/10.5430/ijfr.v11n1p82

\begin{abstract}
This study examined the impact of monetary policy on financial stability in the Nigerian banking industry for the period 2008Q1 to 2016Q2, using an error correction model. Banking industry financial stability index (BIFSI) was computed within the study and was used as a measure of financial stability in the Nigerian banking industry. The study discovered that the impact of monetary policy on financial stability in the Nigerian banking industry was weak. It also revealed a significant long run equilibrium relationship between monetary policy and financial stability in the Nigerian banking industry with a speed of adjustment to long run equilibrium of $66.54 \%$. It was concluded that open market operation and exchange rate channels are more effective channels of transmitting monetary policy to financial stability in the banking industry, than interest rate channel.
\end{abstract}

Keywords: financial stability, monetary policy, Z-Score, financial soundness indicators, monetary policy rate, deposit money banks, global financial crisis

\section{Introduction}

Regular financial stability assessment and the detection of early warning signals to impending risks to the banking industry are major tasks of central banks and other supervisory authorities. Therefore using monetary policy, the central bank aims at preventing costly banking industry crises and financial instability. Financial stability is generally defined as the ability of the financial system to withstand shocks, as well as imbalances, and still continue to adequately provide financial intermediation. The banking industry is a subset of the financial system hence, its ability to withstand both internal and external shocks has been a major concern to economists and regulators. The global experience however, shows that sometimes the banking industry was not able withstand shocks and financial imbalances. Such situations are referred to as financial instability.

Financial instability in the banking industry was manifest during the Great Depression of 1929 to 1933 . Similarly, the recent global financial crisis which began in 2007 and became exacerbated in 2008 with the collapse of a US investment bank (Lehman Brothers) paralyzed the global financial system. Several bail-out packages by the government of some countries were needed to resuscitate the global economy. For instance, in the United States of America, \$115 billion dollars was disbursed to eight banks as bailout funds in 2008 (Congressional Budget Office, 2009). France and United Kingdom also announced bailout plans of $\$ 500$ billion and $\$ 850$ billion respectively in 2008 (Congressional Research Service, 2010), and the Central Bank of Nigeria (CBN) bailed out eight distressed banks in the country to the tune of $\$ 620$ billion in 2009 (CBN, 2009; Sanusi, 2010). Many economists however, believe that banking industry instability is part and parcel of business cycle which occurs due to unrealistic responses and biased expectations by market participants (Allen, Babus, \& Carletti, 2009).

In Nigeria, different monetary policy approaches have been adopted during the various financial development eras of the banking industry in a bid to ensure financial stability. However, various cases of financial instability were witnessed in the industry within the different eras classified as the pre Structural Adjustment Programme (SAP)-1970 to 1985 , the SAP (1986 to 1999) and the Millennium (2000 to 2016) eras.

The pre-SAP era (1970 to 1985) marked the period before the introduction of SAP in 1986. During this period, the direct monetary policy approach was in use. This approach made use of sectoral allocation and credit ceiling tools in 
monetary policy management. This was a period of intensive banking regulation following the establishment of the CBN in 1958. Hence, with severe regulation of interest rates and exchange rates, the banking industry witnessed relative financial stability. This manifested in lack of major banking industry crises during this period, as the CBN effective controlled the banking industry.

During the SAP era which spanned through 1986 to 1999, the indirect monetary transmission system was adopted. This made use of open market operation, reserve requirement and moral suasion to manipulate monetary variables so as to achieve desired policy objectives. However, monetary policy direction and the institutional framework provided by the CBN to control the banking environment could not resolve the problem of financial instability in the banking industry. Inadequate capital base, bad loans, liquidity and poor management problems persisted in the industry which made many banks unable to withstand shocks during this period. Consequently, 5 banks were liquidated in 1994,17 were distressed in 1995 and were taken over by the CBN and 1 was liquidated in 1996. Furthermore, the amendment of the Bank and Other Financial Institutions Act (BOFIA) in 1991 led to the revocation of licenses of 27 banks in 1998 (Uzoaga 1981, Elegbe 2013).

The millennium era was the period from 2000 to 2016. In this era, the indirect monetary policy method continued to be in use. However, financial instability appears to be greatest in this era. For instance, the bank consolidation exercise of 2005 resulted in the total number of deposit money banks (DMBs) being reduced from 89 in 2005 to 24 in 2008 (CBN, 2009). However, the continued instability in the banking industry in 2009 necessitated the CBN to conduct a special audit of all the 24 banks to ascertain the state of their financial health. The result of the audit showed that many of the banks had serious liquidity and capital adequacy problems (CBN, 2009). This led to the injection of $\$ 620$ billion bail-out funds into eight banks in 2009. The banks were: Afribank Plc, Finbank Plc, Oceanic Bank Plc, Union Bank Plc, Intercontinental Bank Plc, Platinum Habib Bank Plc (Bank PHB), Equatorial Trust Bank Ltd and Spring Bank Plc. The board of directors of these eight banks were changed while three of them (Afribank Plc, Bank PHB and Spring Bank) were nationalized and later sold off by the CBN (Proshare, 2009; CBN, 2009; Chiejine, 2010). Subsequent mergers/acquisitions reduced the number of banks to 19 in 2015 (CBN, 2015). The CBN has also adopted several other supervisory measures termed macro-prudential policies in addition to monetary policy so as to effectively control the banking industry. However, these measures by the CBN did not solve the problem of financial instability as many banks continued to suffer capital inadequacy and assets quality problems (CBN, 2015).

From the establishment of the CBN in 1958, the apex bank has adopted several measures within the ambit of monetary policy to encourage financial stability in the banking industry. Other supervisory measures such as the establishment of the prudential guidelines for banks following the enactment of BOFIA in 1991 were also adopted. These measures intended to address the issues of incessant bank distress, bank failures and financial instability in the industry in general. However, despite the actions of the CBN, financial instability still persists in the banking industry in Nigeria. The industry still lacks the ability to withstand shocks (both internal and external) as could be seen from the rate of bank failures, capital inadequacy and liquidity problems it grapples with. For instance, financial instability in the banking industry led to the collapse of many banks evidenced by the decrease in the number of DMBs from 89 in 2005 to 20 in 2012 (IMF, 2013). The number of DMBs was further reduced to 19, with the acquisition of Enterprise bank by Heritage bank in 2015 (CBN, 2015).

The underperformance of the banking industry could be attributed to weak monetary policy measures and lack of strong supervisory disposition of the CBN. For instance, the monetary policy rate (MPR) which is the benchmark interest rate has remained double digit between 2011Q4 and 2016Q2. The MPR which was 9.5\% in 2008Q1 increased steadily up to $13 \%$ in 2015Q3. It declined marginally to $11 \%$ in 2015Q4 but still increased to $12 \%$ in 2016 (CBN, 2016). This appeared to have contributed to the high lending rate experienced in the banking industry, with the concomitant adverse effects on banks income and profitability. This discourages borrowing and increases loan default rate. Lack of adequate income and the erosion of banks' capital base due to increased bad loans, weakened the ability of banks to withstand shocks and provide financial intermediation.

Furthermore, the less effective open market operation (OMO) activity of the CBN which reflected in the highly oscillatory nature of the treasury bill rate over the years might have contributed to weaken financial stability in the banking industry. For instance, the TBR which was $8.5 \%$ in 2008Q1 fell to $3.32 \%$ in 2009Q2 but rose steadily to $8.49 \%$ in 2011Q3. It jumped sharply to $14.23 \%$ in $2011 \mathrm{Q} 4$ and remained at double digit up till 2014Q1 when it was $11.92 \%$ (CBN, 2016). This erratic movement in the TBR makes it difficult for the CBN to control liquidity as the rates are most times not impressive to money market participants. Hence in periods of economic boom, the excess liquidity resulting 
from the inability of the CBN to effectively mop-up liquidity tends to produce financial imbalances which ultimately results in financial instability in the banking industry.

The exchange rate policy appears not to have yielded the required results due to policy inefficiency. Continuous fall in the value of the local currency (the Naira), against other major currencies has been experienced over the years. For instance, the official Naira-US Dollar exchange rate which was \$116.79 in 2008Q1 depreciated to \$231.76 in 2016Q2, almost 100\% depreciation in 8 years (CBN, 2016). This sustained depreciation of the Naira was also accompanied by erratic foreign exchange market activities which plausibly led to several bad debt portfolios in the banking industry. Hence, financial stability in the industry was negatively affected.

Given the foregoing, it became germane to investigate these banking instability issues in Nigeria in the face of varying monetary policy measures by the $\mathrm{CBN}$. Thus, this study examined the impact of monetary policy on financial stability in the Nigerian banking industry from 2008Q1 to 2016Q2 by examining specifically, the impacts of monetary policy tools of monetary policy rate, open market operation and exchange rate respectively on financial stability in the Nigerian banking industry. Deposit money banks (DMBs) were used to represent the banking industry in Nigeria. This is because DMBs dominate the banking industry in terms of assets and deposit liabilities (CBN, 2015). Furthermore, this study focused on the industry as a whole (macro-analytical) and not on individual banks (micro-analytical). It is believed that this engendered a holistic assessment of the subject matter of the study.

The remaining part of this study is structured such that the next section examined empirical literature and theoretical framework. Section three and four are methodology and results analysis respectively. Section five is the concluding section.

\section{Empirical Literature and Theoretical Framework}

\subsection{Empirical Literature}

Many economists believe that a financially stable banking system is able to withstand systemic shocks, avoid financial crisis, ensures efficient resource allocation within the economy and maintains investors as well as public confidence in the system. It also ensures the smooth running of all the components of the system so as to positively influence economic performance. However, measurement of financial stability varies due to the complex nature of the phenomenon. These measurements aim at providing an idea on the soundness and dependability of the financial system. IMF (2006) indentified 24 financial soundness indicators (FSIs) for the assessment of soundness of banks based on a framework commonly referred to as the CAMELS - capital adequacy, asset quality, management quality, earnings and profitability, liquidity, and sensitivity to market risk. This was grouped under capital based, assets based and income/expense based indicators. Similarly, Bank Z-Score has been identified as a measure of financial stability. According to World Bank (2016), "A common measure of stability at the level of individual institutions is the z-score. It explicitly compares buffers (capitalization and returns) with risk (volatility of returns) to measure a bank's solvency risk. To measure systemic stability, a number of studies attempt to aggregate firm-level stability measures (z-score and distance to default) into a system-wide evaluation of stability by averaging or by weighting each measure by the institution's relative size". Several studies have employed Z-Score as a measure of financial stability. Such studies include: Amidu and Wolfe (2013), Fernández, A. I., Gonzalez F. and Suarez N. (2014), Mensi and Labidi (2015), and Soedarmono, W., Machrouh F. \& Tarazi A. (2011).

Financial and macroeconomic conditions are closely linked. Intense financial instability in the banking industry could disrupt the monetary transmission mechanism that links monetary policy to the real economic variables. Two major beliefs concerning the association between monetary policy and financial stability exist in literature. The first belief proposes a synergy between the two. It was argued that stable prices generate an atmosphere of predictable interest rates, resulting in a lower risk of interest rate mismatch that tends to reduce the long run inflation risk premium and engender financial stability. Thus, monetary policy should be employed to foster price stability and financial stability (Schwart, 1995; Bernanke \& Gertler, 1999; Herrero \& Lopez, 2003). Conversely, the other belief opines the existence of a trade-off between monetary policy and financial stability (Graeve, Kick \& Koetter, 2008). Some economists like Christensen and Meh (2011), Collard F., Dallas H., Diba B., Loisel O (2012), Alpanda and Zubairy (2014) and Svensson (2015) hold the view that monetary policy cannot achieve financial stability, instead emphasis should be on macro-prudential or regulatory tools to address financial imbalance in the banking industry.

Some studies have examined the nature of the association between monetary policy and financial stability as well as what causes financial instability in the banking industry. Graeve, et al (2008), employed the logit model and vector autoregressive (VAR) model in their study on "Monetary policy and financial (in) stability: An integrated micromacro approach". The study focused on the banking industry in Germany and employed quarterly macroeconomic 
data for the period 1995 to 2004 . The results showed a trade-off between monetary policy and financial stability, implying that the contraction of former raises the likelihood of bank failure. The results also showed that low capitalization increases the probability of financial instability. Therefore, the study advocates for increased supervision in addition to monetary policy among central banks and other regulatory agencies.

Granville and Mallick (2009) investigated the association between financial stability and monetary policy in the European Economic and Monetary Union for the period 1994 to 2008, using a vector autoregressive (VAR) model. The study discovered a long-run pro-cyclical correlation between monetary and financial stability. They concluded that monetary policy measure of using interest rate tool for inflation targeting engenders financial stability.

Tabak, Laiz and Cajueiro (2010) adopted the feasible generalized least squares (FGLS) estimation technique in their study on financial stability and monetary policy - The case of Brazil. The study made use of panel data covering 99 banks for the period 2003 to 2009. Bank z-score, assets quality (the ratio of non-performing loans to total gross loans) and credit risk exposure were adopted as measures of financial stability. The result shows that there exists a significant association between assets quality and monetary policy, lower monetary policy rate increases banks' risk taking while high interest rates increases bank's credit exposure which may adversely affect financial stability. Furthermore, the study revealed that banks with large amount of capital and high liquidity position are able to withstand monetary policy shocks, while banks increase their loans during periods of expansionary monetary policy.

Dhal, Kumar and Ansari (2011) in their study on financial stability, economic growth, inflation and monetary policy linkages in India: An empirical reflection, adopted the (VAR) model consisting of macroeconomic indicators and a banking industry stability index (proxied by CAMEL) indicators. The study covered the period 1995Q2 to 2012Q3. The results indicate that "financial stability and macroeconomic indicators comprising output, inflation and interest rates share a statistically significant bi-directional Granger type causal relationship. Hence, price instability could adversely affect financial stability while financial stability contributes to the effectiveness of monetary transmission mechanisms".

Ngakosso (2016) investigated the association between monetary policy and financial stability in the Economic and Monetary Community of Central Africa (CEMAC) zone countries. The Taylor increased rule estimation method was adopted for the study using annual data covering the period 1980 to 2013. The result rejects the integrated policy mix approach whereby monetary policy is used alongside macroprudential policy in a bid to ensuring financial stability. It shows however, that macroprudential policy is the most suitable policy to ensure financial stability.

Some studies have tried to elucidate on the factors responsible for financial instability and banking crises in Nigeria. The implications of this to financial intermediation were also highlighted. Adeyemi (2011) adopted survey method to study "bank failure in Nigeria: a consequence of capital inadequacy, lack of transparency and non-performing loans?" The study showed that inadequate capital, lack of transparency and bad loans are responsible for financial instability in the banking industry and bank failures in Nigeria. Other studies by Ohwofasa and Mayuku (2012), Mayuku, G., Ogude B., Ibeh S., and Oluwafase B. (2012) and Elegbe (2013) revealed that ineffective monetary policy and inadequate supervision by the regulatory authorities were partially responsible for the bank failures witnessed in the country.

Nwosu et al. (2012) adopted a combination of the pooled ordinary least squares (POLS) and the generalized moment method (GMM) to examine the effect of bank recapitalization on the risk taking behavior of deposit money banks in Nigeria using panel data covering the period 2001 to 2008. Using bank z-score to represent aggregate risk of insolvency (or financial stability) they observed that increased bank capitalization promotes financial stability in the banking industry. Conversely, banks with low capitalization levels tend to suffer financial instability. The result further shows that while growth capital base is a positive linear determinant of banking stability, growth in size is non linear.

From the foregoing review, it is evident that there is dearth of studies in this area especially in a developing sub-Sahara African country such as Nigeria. Most of the studies like Graeve et al (2008), Granville and Mallick (2009), Tabak et al. (2010), Ngakosso (2016), etc were not localized to Nigeria. Besides, they focused mainly on individual banks (micro) rather than the banking industry as a whole (macro). The few studies that were carried out in Nigeria like Adeyemi (2011), Nwosu et al. (2012) and Egbo (2012) were not robust They were majorly on banking distress which is just an aspect of banking industry financial instability. They did not take a holistic approach towards ascertaining monetary policy impact on the banking industry stability as a whole. Furthermore, none of the studies reviewed used an index of financial stability constructed within the study. They used stability indexes from secondary sources. 
This work therefore differs from other studies reviewed above. Hence this study makes an improvement by examining the issue of the financial stability in the banking industry at the industry level (macro) and not at the individual bank level (micro). Besides, unlike other studies, banking industry stability index (Z-score) constructed within the study was used to measure financial stability in the industry. These differing approaches make this study more pragmatic.

\subsection{Theoretical Framework}

Theoretical literature shows that banking systems influence sustained economic progress through the process of financial intermediation and that developed financial systems contribute positively to economic growth. Improvements in the banking sector aid savings and capital formation and ease the external financing constraints that firms and households face; this will lead to higher growth. Theoretical evidence suggests that in the long run, a well developed financial system has a high salutary effect on economic growth (Levine, 2005).

The financial system fragility hypothesis also known as the financial instability hypothesis was postulated by Hyman Minsky (1972; 1980). Minksy believes that financial crisis is prevalent in capitalism since periods of economic opulence encourage borrowers and lenders to be progressively out of control. This excessive optimism generates financial bubbles which later bust. This hypothesis holds that dynamics of business investment finance prevalent in the business cycles is the persistent cause of financial instability. Consequently, business cycles are complicated by (i) the inherent dynamics of market economies, and (ii) the structure of policies initiated to maintain the economy at acceptable boundaries. During the boom phases of the business cycle, the growth of debt-financed investments results in initial "robust" financial structures evolving into "fragile" financial structures. It is this development that eventually brings the expansion to a stop. Following this is a contraction in which various fragile financial structures crumple leading to financial instability.

\section{Research Methodology}

\subsection{Model Specification}

The theoretical underpinning of the models for this study is a combination of the Keynesian monetary transmission theory and the financial system fragility hypothesis. The financial system fragility hypothesis postulated by Hyman Minsky $(1972 ; 1980)$ explains the conditions for financial stability while the Keynesian monetary transmission theory emphasized the importance of monetary policy in ensuring financial stability and economic progress. This study measured financial stability by adopting the categorization of financial stability indicators (FSIs) by IMF (2006) with emphasis on the banking industry. This categorization specified the indices to measure financial stability in the banking industry.

This study constructed a banking industry financial stability index (BIFSI) for Nigeria. This BIFSI is the z-score for the Nigerian banking industry. The BIFSI was employed as a measure for financial stability in the banking industry, while monetary policy was represented by interest rate (monetary policy rate) and treasury bill rate (proxy for open market operation) based on the Keynesian monetary transmission theory. Exchange rate is also included to represent monetary policy so as to reflect the peculiarities of the Nigerian economy. Investment (gross fixed capital formation) was included in the model, as a control variable in line with the financial system fragility hypothesis. Consequently, the relationship between monetary policy and financial stability in the banking industry is expressed as follows:

$\mathrm{BIFSI}_{\mathrm{t}}=\mathrm{f}\left(\mathrm{MPR}_{\mathrm{t}}, \mathrm{TBR}_{\mathrm{t}} \mathrm{EXR}_{\mathrm{t}}, \mathrm{GFCF}_{\mathrm{t}}\right)$

Specifying into an econometric model implies

$$
\text { BIFSI }_{t}=\alpha_{0}+\alpha_{1} \text { MPR }_{t}+\alpha_{2} \text { TBR }+\alpha_{3} \text { EXRt }+\alpha_{4} \mathrm{GFCF}_{\mathrm{t}}+\mathrm{U}_{\mathrm{t}}
$$

Where:

BISFI= Financial stability in the banking industry (proxied by banking industry financial stability index).

MPR= Monetary policy rate (proxy for interest rate).

$\mathbf{T B R}=$ Treasury bill rate. This is the rate at which the $\mathrm{CBN}$ buys/sell securities during open market operation (OMO)

$\mathbf{E X R}=$ Exchange rate. This is the Naira to US dollar exchange rate.

GFCF $=$ Gross fixed capital formation (Investment).

$\mathbf{U}=$ stochastic error term

$\mathbf{t}=$ measure of time

$\alpha_{1}>0 ; \alpha_{2}>0 ; \alpha_{3}<0 ; \alpha_{4}>0$ (economic a-priori criteria) 
Table 1. Individual indicators for BIFSI

\begin{tabular}{|c|c|c|c|}
\hline Category & Indicator & Notation & Impact \\
\hline \multicolumn{4}{|c|}{ 1. Banking soundness Index } \\
\hline & Capital adequacy ratio & CAR & + \\
\hline Capital adequacy & Ratio of non-performing loans net of provisions to capital & NPLP/C & - \\
\hline \multirow[t]{2}{*}{ Asset quality } & Ratio of non-performing loans to total gross loans & NPL/TL & - \\
\hline & Ratio liquid assets to total assets & $\mathrm{LA} / \mathrm{TA}$ & + \\
\hline \multirow[t]{3}{*}{ Liquidity } & Loans to deposits ratio & TL/D & - \\
\hline & Return on assets & ROA & + \\
\hline & Interest margin to gross income ratio & NIM & + \\
\hline Profitability & Non-Interest Expense to Gross Income & NIE/GI & - \\
\hline \multicolumn{4}{|c|}{ 2. Banking Vulnerability Index } \\
\hline & Current account balance to GDP Ratio & $\mathrm{CAB} / \mathrm{GDP}$ & + \\
\hline & Ratio of external assets to total assets of DMBs & EA/TA & - \\
\hline External Sector & $\begin{array}{l}\text { Ratio of foreign currency assets to foreign currency Liabilities of } \\
\text { DMBs }\end{array}$ & FCA/FCL & + \\
\hline \multirow[t]{2}{*}{ Financial Sector } & DMBs domestic credit to GDP & $\mathrm{DC} / \mathrm{GDP}$ & + \\
\hline & Inflation & INF & - \\
\hline Real Sector & GDP growth rate & GDPR & + \\
\hline \multicolumn{4}{|c|}{ 3. World Economic Climate Index } \\
\hline & GDP growth rate of the US & GDPRUS & + \\
\hline & GDP growth gate of China & GDPRCH & + \\
\hline
\end{tabular}

Source: Author's compilation

\subsection{Construction of the Banking Industry Financial Stability Index (BIFSI)}

Based on the IMF-FSIs compilation guide 2006 and following studies by Verlis, (2011); Sere-Ejembi, A., Udom, I.S., Salihu, A., Atoi. N.V and Yaaba, B.N (2014) and Kristína (2015), the BIFSI was developed using 16 individual financial stability indicators as shown in the table 1 above.

The BIFSI model is specified as follows:

$$
\mathrm{BIFSI}_{\mathrm{t}}=w 1 \mathrm{BSI}_{\mathrm{t}}+w 2 \mathrm{BVI}_{\mathrm{t}}+w 3 \mathrm{WECI}_{\mathrm{t}}
$$

Where:

BIFSI= Aggregate banking industry financial stability index for Nigeria

BSI = Banking soundness index

$\mathrm{BVI}=$ Banking vulnerability index

WECI $=$ World economic climate index

$\mathrm{W} 1=$ weight assigned to BSI 
$\mathrm{W} 2=$ weight assigned to BVI

W3= weight assigned to WECI

$\mathrm{t}=$ time (quarter in the review period)

$$
\sum_{i=1}^{3} \mathrm{Wi}=1
$$

\subsubsection{Description of Indicators}

The individual indicators are classified into three broad categories, namely banking industry soundness index (BSI), banking vulnerability index (BVI) and world economic climate index (WECI). These are explained below:

(a) Capital adequacy

i. CAR: This evaluates banks' ability to absorb unanticipated losses. It shows the ability of the industry to withstand shocks to the industry's statement of financial position. Higher values for this ratio indicate better financial healthiness of the industry.

ii. NPLP/C: NPLP/C indicates the ability of bank capital to withstand potential losses arising from non-performing loans. Higher values of this indicator impact negatively on financial stability of the industry.

(b) Asset Quality

i. NPL/TL: Non Performing loans affect the quality of bank's risk assets. Hence, this ratio seeks to discern problems with asset quality in the credit portfolio. The higher the ratio the worse it is for the industry.

(c) Liquidity

i. LA/TA: This ratio measures the banks' capacity to meet short term financial obligation and customers demand for cash. The higher the ratio the better it is for financial stability. The CBN usually prescribes the minimum acceptable value for this ratio.

ii. TL/D: The ratio indicates the percentage of depositors' funds that are given out as loans. High values for this ratio may expose the banks to not being able to meet obligations due depositors at all times.

(d) Profitability

i. ROA: This ratio assess banks' efficiency in assets usage and shows the ability of the banks to mitigate potential business risks. The higher the ratio the better for the industry.

ii. NIM: NIM assesses the relative share of interest earned less interest expenses (net interest income) within gross income. The higher the ratio the better.

iii. NIE/GI: This ratio assesses the degree to which high non-interest expenses erode earnings. A high ratio indicates inefficiency.

(e) External sector

i. CAB/GDP: This portrays the ability of the country as a whole to meet short term obligations to its trading partners.

ii. EA/TA: The ratio assesses the level of the local banking sector in relation to the external world.

iii. FCA/FCL: It assesses the divergence of foreign currency asset in relation to liability positions and also assesses the susceptibility of banks to foreign exchange fluctuations.

(f) Financial sector

i. DC/GDP: A high measure depicting rapid loan growth compared to GDP growth precedes declining loan standards, system instability and precedes banking crisis. The regulators usually set a ceiling for this indicator.

(g) Real sector

i. INF: The inflation rate is an important factor in determining inter-bank, lending and deposit rates. Banks usually absorbs the impact of high inflation rate with upward review of lending rates.. The lower the rate the better.

ii. GDPR: This provides a linkage between the real sector and the financial sector. A declining rate slows down economic activities. The higher the rate the better. 
(h) World economic climate index

This is represented by GDPRUS and GDPRCH. These are the GDP growth rates of major trading partners of Nigeria that account for a high percentage of Nigeria's international trade transactions.

\subsection{Construction of the Aggregate Banking Industry Financial Stability Index for Nigeria}

Prior to the last aggregation, the various data underwent a procedure of normalization and weight allocation so as to bring them to a common scale (Nicholas and Isabel, 2010). Consequently, all individual indicators were normalized to make them assume equal variance. Two main methods of normalization could be identified namely: statistical normalization and empirical normalization.

The statistical normalization method translates indicators to an identical scale having a mean $=0$ and standard deviation $=1$. The outcome is a Z-score for the variable. The zero mean prevents introducing aggregation bias emanating from disparities in the individual indicator's means. The scaling parameter is the standard deviation. Hence, an indicator with high value will fundamentally exert a higher impact on the combined indicator (Kristína, 2015). The statistical normalization method is given by:

$$
\mathbf{Z}_{\mathbf{t}}=\left(\mathbf{X}_{\mathrm{it}}-\mathbf{x}\right) / \mathbf{s}
$$

Where:

$\mathrm{X}_{\mathrm{it}}=$ value of indicator $\mathrm{X}_{\mathrm{i}}$ during period $t$.

$\overline{\mathbf{x}}=$ mean

$\mathrm{s}=$ standard deviation

$Z_{\mathrm{t}}=$ normalized value of the indicator.

The empirical normalization method translates all indicators to equal range of 0 or 1 . It uses the range (Max - Min) instead of standard deviation as the scaling parameter. The value of 0 (Min) symbolizes most unfavourable while the value 1 (Max) symbolizes the most favourable value. One major shortcoming of this method is that the minima and maxima could distort the normalized indicators as they are majorly unreliable pointers.

For this study, the statistical normalization method has been adopted so as to avoid the shortcomings of the empirical method as discussed above. All the individual indicators were converted such that a higher value implies an enhancement in financial stability while a lower value implies a decline. Thus for indicators that have inherent negative impact on financial stability (NIE/GI, NPL/TL, (NPL-P)/C, etc) the reciprocal values were used.

\subsection{The Aggregate Index}

All individual indicators were normalized by subtracting each observation from the mean of the individual indicator and dividing the outcome by the standard deviation of the indicator. The result is a z-score for that indicator given by:

$\mathrm{Z}_{\mathrm{t}}=\left(\mathrm{X}_{\mathrm{it}}-\mathrm{x}\right) / \mathrm{s}$ (where all the variables are as defined in equation 4). The normalized indicators were then combined into a single index. All individual indicators were assigned equal weights so as to compute the composite indices of BSI, BVI and WECI. Hence, the indices conferred equal significance to every single indicator. This is the most frequently used weighting method in literature. The normalized variables were combined to form an aggregate index by employing the arithmetic mean, as given by the formulas below:

$$
\begin{aligned}
& \overline{\mathrm{S}_{\mathrm{t}}}=\sum_{\frac{i=1}{8}}^{8} \mathrm{BSI}_{\mathrm{it}} \\
& \overline{\mathrm{V}_{\mathrm{t}}}=\sum_{i=1}^{7} \mathrm{BVI}_{\mathrm{it}} \\
& \overline{\mathrm{E}_{\mathrm{t}}}=\frac{\sum_{i=1}^{2}}{2} \mathrm{WECI}_{\mathrm{it}}
\end{aligned}
$$

(5) (Banking soundness index)

(6) (Banking vulnerability index)

(7) (World economic climate index) 
The next step entails the weighting of the average values of the sub indices so as to show their importance to the stability of the banking industry. According to Illing and Liu (2003); and Maliszewski, (2009), several methods of assigning weights to sub-indices exist. These include estimation of a logit model, expert judgment, standardization (variance-equal weights), market segment size, etc. Consequently, this study adopted the variance-equal weights method. This method creates an index that allocates the same weights to all sub-indices, indicating equal significance to each indicator. This is the most popular weighting technique employed in modern studies (Kristína, 2015). Therefore, equal weights were assigned to the sub-indices as follows:

$$
\mathrm{W} 1=\mathrm{W} 2=\mathrm{W} 3=1 / 3
$$

Lastly, the aggregate banking industry financial stability index was constructed as follows:

$$
\text { BIFSI }_{t}=1 / \overline{3 S_{t}}+1 / 3 \overline{V_{t}}+1 / \overline{E_{t}}
$$

The values obtained from equation 9 were used in the estimation of equation 1 . However, before estimating equation 1 several diagnostic tests were carried out on the data, after which appropriate estimation technique was applied.

\subsection{Sources of Data Collection}

Data for this study are time series quarterly data obtained from secondary sources. They were obtained from the CBN statistical bulletin (2014 to 2016), the CBN financial stability report (various issues) and several bulletins of the National Bureau of Statistics.

\subsection{Model Estimation Technique}

This study adopted a dynamic estimation technique. Based on this technique, if all the variables of the model are integrated of order one - I(1), and are cointegrated, then the appropriate method to estimate the model is an error correction model (Engle \& Granger, 1987). Thus the error correction model (ECM) was adopted so as to evaluate the short-run dynamics and the adjustments to long-run equilibrium. The choice of ECM was to eliminate spurious regression. Furthermore, the ECM incorporates the short run dynamics into the long run equilibrium without any information loss. Unit root test was employed to establish the stationarity condition of time series economic variables used in this study. That is whether such variables are stationary or non-stationary.

\section{Empirical Results}

\subsection{Normalization of Financial Stability Indicators, FSIs (Statistical Normalization Method)}

In the statistical normalization method, each observation was subtracted from the mean of the indicator and the resulting quantity was divided by the standard deviation of the indicator to derive the z-score of that particular indicator. By aggregation and assigning of weights, the BIFSI was derived as shown in tables 2, 3, 4 and 5 below. 
Table 2. Normalized series of financial stability indicators (statistical normalization method)

\begin{tabular}{|c|c|c|c|c|c|c|c|c|c|c|c|c|}
\hline & \multicolumn{4}{|c|}{2008} & \multicolumn{4}{|c|}{2009} & \multicolumn{4}{|c|}{2010} \\
\hline $\begin{array}{l}\text { soundness } \\
\text { Index }\end{array}$ & Q1 & Q2 & Q3 & Q4 & Q1 & Q2 & Q3 & Q4 & Q1 & Q2 & Q3 & Q4 \\
\hline CAR & 0.9883 & 1.2966 & 1.1645 & 1.0323 & 1.0764 & 1.1057 & $0.2379^{\circ}$ & $1.5815^{\circ}$ & $1.7724^{\circ}$ & $1.9633^{\circ}$ & -1.9413 & -1.9192 \\
\hline NPLP/C & 2.1836 & 1.6793 & 0.3345 & -0.1827 & -0.3659 & -0.4993 & 1.1690 & 1.2474 & 1.2931 & 1.3100 & -1.3026 & -1.2916 \\
\hline NPL/TL & $\begin{array}{l}0.8794 \\
1.5125\end{array}$ & $\frac{0.7389}{2.0111}$ & $\begin{array}{l}0.1432 \\
1.0693\end{array}$ & $\begin{array}{r}-0.2350 \\
0.1274\end{array}$ & $\begin{array}{r}-0.4868 \\
-0.1496\end{array}$ & $\begin{array}{c}-0.6734 \\
-0.4266\end{array}$ & 1.3376 & 1.5422 & 1.5504 & $\frac{1.5583}{0.0166}$ & $\begin{array}{r}-1.4492 \\
0.0166\end{array}$ & $\begin{array}{r}-1.2491 \\
0.0166\end{array}$ \\
\hline $\begin{array}{l}\text { LA/TA } \\
\text { TL/D }\end{array}$ & 0.5494 & 1.1056 & 1.0379 & 1.3932 & 1.3731 & 1.2537 & $\begin{array}{l}0.3019 \\
1.8008\end{array}$ & $\begin{array}{l}0.1773 \\
1.2434\end{array}$ & $\begin{array}{l}0.0803 \\
0.9627\end{array}$ & 0.8875 & 0.8817 & -0.5941 \\
\hline ROA & 1.0730 & 0.4897 & 0.8230 & 1.1564 & 0.7397 & 0.3230 & $1.8853^{\circ}$ & 4.0936 & 2.0311 & 0.0314 & 0.6355 & 1.2397 \\
\hline NIM & 1.1199 & 0.5205 & -0.1952 & 0.1130 & 0.2671 & 0.4212 & 0.2329 & 0.0274 & 0.2979 & 0.6233 & -0.6490 & -0.6747 \\
\hline $\begin{array}{l}\text { NIE/GI } \\
\text { 2. Banking } \\
\text { Vulnerability } \\
\text { Index }\end{array}$ & 1.6407 & 1.2681 & 1.1000 & 0.9370 & 0.5089 & 0.1292 & 1.0029 & 1.8915 & 1.8577 & 1.8236 & -1.0973 & -0.2233 \\
\hline $\mathrm{CAB} / \mathrm{GDP}$ & 2.5693 & 2.6788 & 2.2445 & -0.8413 & -0.1387 & 0.1918 & 0.5460 & 1.7814 & 0.3633 & 0.0678 & -0.3027 & 0.3887 \\
\hline EA/TA & 0.8326 & 0.6329 & -0.1860 & 1.1312 & 0.5409 & -0.3252 & 0.5595 & 0.6999 & 0.5498 & 0.9373 & -0.2627 & -0.4901 \\
\hline $\mathrm{FCA} / \mathrm{FCL}$ & 1.2523 & 1.9644 & 1.2756 & 2.3349 & 1.4044 & 0.8862 & 0.7457 & 0.3156 & 0.4366 & 0.2927 & 0.3959 & 0.3336 \\
\hline $\begin{array}{l}\text { DC/GDP } \\
\text { IN } \\
\text { F } \\
\end{array}$ & $\begin{array}{l}0.0097 \\
1.5495\end{array}$ & $\begin{array}{l}0.3367 \\
0.5741 \\
\end{array}$ & $\begin{array}{r}0.1374 \\
-0.8624\end{array}$ & $\begin{array}{r}0.5267 \\
-1.3474\end{array}$ & $\begin{array}{r}0.9413 \\
-1.1988\end{array}$ & $\begin{array}{r}1.2037 \\
-0.2767\end{array}$ & $\begin{array}{l}1.6352 \\
0.0441\end{array}$ & $\begin{array}{r}2.2029 \\
1.0963 \\
\end{array}$ & $\begin{array}{l}0.1383 \\
1.2952 \\
\end{array}$ & $\begin{array}{l}0.1438 \\
1.1367\end{array}$ & $\begin{array}{r}0.0284 \\
-1.0276\end{array}$ & $\begin{array}{c}-0.1965 \\
-0.4988\end{array}$ \\
\hline $\begin{array}{l}\text { GDPR } \\
\text { 3. World } \\
\text { Economic } \\
\text { Climate Index }\end{array}$ & 0.6346 & 0.7841 & 0.9767 & 1.0450 & 1.3069 & 1.0522 & 0.7056 & 0.9016 & 0.7764 & 0.9316 & 0.8357 & 0.3114 \\
\hline GDPRUS & 0.0757 & 0.2155 & -0.8136 & -2.0845 & -2.4413 & -2.7555 & 2.3527 & 0.7757 & 0.1774 & 0.7578 & 0.9428 & 0.7640 \\
\hline GDPRCH & 0.9308 & 1.0846 & 1.0077 & 0.6231 & 0.4692 & 0.7000 & 0.6231 & 0.8538 & 1.1615 & 1.4692 & 1.7769 & 1.5462 \\
\hline
\end{tabular}

Source: Author's computation

Table 3. Normalized series of financial stability indicators (statistical normalization method) - continued

\begin{tabular}{|c|c|c|c|c|c|c|c|c|c|c|c|c|}
\hline & & 20 & & & & 20 & & & & 20 & & \\
\hline $\begin{array}{l}\text { soundness } \\
\text { Index }\end{array}$ & Q1 & Q2 & Q3 & Q4 & Q1 & Q2 & Q3 & Q4 & Q1 & Q2 & Q3 & Q4 \\
\hline CAR & -1.7430 & -1.5668 & -0.5536 & 0.4449 & 0.4302 & 0.4156 & 0.4596 & 0.5037 & 0.5477 & 0.5918 & 0.4596 & 0.3275 \\
\hline NPLP/C & -1.2672 & -1.2040 & -1.0950 & -0.2980 & 0.1244 & 1.1164 & 1.2684 & 1.4404 & 0.8371 & 0.4485 & 0.4638 & 0.4794 \\
\hline$\frac{\text { NPL/TL }}{\text { LA/TA }}$ & $\begin{array}{r}-1.1234 \\
0.7645\end{array}$ & $\begin{array}{r}-0.9407 \\
1.5125\end{array}$ & $\begin{array}{r}-0.6032 \\
1.9418\end{array}$ & $\begin{array}{l}0.0846 \\
2.3712\end{array}$ & $\begin{array}{l}0.2054 \\
0.7922\end{array}$ & $\begin{array}{r}0.3416 \\
-0.7867\end{array}$ & $\begin{array}{r}0.6739 \\
-0.5235\end{array}$ & $\begin{array}{r}1.1201 \\
-0.2604\end{array}$ & $\begin{array}{r}0.9552 \\
-0.6066\end{array}$ & $\begin{array}{r}0.8073 \\
-0.9529\end{array}$ & $\begin{array}{r}0.9948 \\
-0.5235\end{array}$ & $\begin{array}{r}1.2097 \\
-0.0942\end{array}$ \\
\hline TLD & -0.8215 & -1.0189 & -1.1045 & -1.0241 & -1.2445 & -0.9059 & -1.0367 & -0.5941 & -1.3955 & -1.0746 & -1.6808 & -1.5149 \\
\hline ROA & 0.6147 & -0.0103 & -0.1770 & -0.3436 & -0.0520 & 0.2397 & 0.1772 & 0.1147 & 0.1564 & 0.1980 & 0.0730 & -0.0520 \\
\hline NIM & -0.9229 & -1.1712 & -1.9075 & -2.6438 & -0.4521 & 1.7226 & 1.2346 & 0.7466 & 1.0205 & 1.2945 & 1.1832 & 1.0719 \\
\hline $\begin{array}{l}\text { NIE/GI } \\
\text { 2. Banking } \\
\text { Vulnerability } \\
\text { Index }\end{array}$ & -0.6298 & -1.0029 & -1.1552 & -1.2911 & -0.2796 & 1.0088 & 0.5254 & 0.0837 & 0.2448 & 0.4113 & -0.0060 & -0.3902 \\
\hline $\mathrm{CAB} / \mathrm{GDP}$ & 0.2598 & 0.4115 & -1.1735 & -0.1611 & 0.0070 & -0.4850 & 0.4860 & -0.0819 & 0.2153 & -0.0998 & -0.2262 & -0.0545 \\
\hline EA/TA & 0.4157 & 1.3009 & 0.5696 & 0.5694 & 1.1855 & 1.0237 & 2.0698 & 1.0972 & 0.8188 & 0.5904 & 0.7987 & 0.4662 \\
\hline FCA/FCL & 0.2664 & 0.3982 & 0.1626 & 0.1321 & 0.4438 & 0.2899 & 0.2655 & -0.1412 & -0.2523 & -0.3717 & -0.4354 & -0.5562 \\
\hline $\begin{array}{l}\text { DC/GDP } \\
\text { INF }\end{array}$ & $\begin{array}{l}-0.2907 \\
-0.7951\end{array}$ & $\begin{array}{r}-0.1845 \\
0.1143\end{array}$ & $\frac{-0.0441}{0.0658}$ & $\begin{array}{l}0.5643 \\
0.0921\end{array}$ & $\begin{array}{r}0.7443 \\
-0.5933\end{array}$ & $\begin{array}{r}0.4495 \\
-0.8263\end{array}$ & $\begin{array}{r}0.2953 \\
-0.2990\end{array}$ & $\begin{array}{r}0.1841 \\
-0.5515\end{array}$ & $\frac{0.2979}{0.9844}$ & $\begin{array}{l}0.1491 \\
1.1404\end{array}$ & $\begin{array}{l}0.0670 \\
1.3847\end{array}$ & $\begin{array}{l}0.2279 \\
1.4140\end{array}$ \\
\hline $\begin{array}{l}\text { GDPR } \\
\text { 3. World } \\
\text { Economic } \\
\text { Climate } \\
\text { Index } \\
\end{array}$ & 0.6073 & 0.3911 & -0.7412 & -0.2964 & -0.8010 & -0.5332 & 0.0666 & -0.7271 & -0.3915 & -0.0033 & -0.0982 & 0.5573 \\
\hline GDPRUS & 0.3300 & 0.2054 & -0.0381 & 0.2207 & 0.7756 & 0.6377 & 0.5898 & 0.0108 & 0.0298 & -0.1140 & 0.2266 & 0.7286 \\
\hline GDPRCH & 1.3154 & 1.0846 & 0.7000 & 0.1615 & -0.3000 & -0.6846 & -0.7615 & -0.3000 & -0.4538 & -0.6846 & -0.4538 & -0.6077 \\
\hline
\end{tabular}

Source: Author's computation 
Table 4. Normalized series of financial stability indicators (statistical normalization method) - continued

\begin{tabular}{|c|c|c|c|c|c|c|c|c|c|c|}
\hline & \multicolumn{4}{|c|}{2014} & \multicolumn{4}{|c|}{2015} & \multicolumn{2}{|c|}{2016} \\
\hline $\begin{array}{l}\text { l. Banking } \\
\text { soundness index }\end{array}$ & Q1 & Q2 & Q3 & Q4 & Q1 & Q2 & Q3 & Q4 & Q1 & Q2 \\
\hline CAR & 0.2761 & 0.2247 & 0.2834 & 0.3421 & 0.3715 & 0.4009 & 0.2907 & 0.1806 & 0.0778 & -0.0250 \\
\hline NPLP/C & 0.5114 & 0.5446 & 0.8371 & 1.2365 & 0.4953 & 0.0846 & 0.0846 & 0.0846 & -0.7549 & -0.9736 \\
\hline NPL/TL & 1.1642 & 1.1201 & 1.4059 & 1.7508 & 0.7727 & 0.2054 & 0.0292 & -0.1202 & -0.7162 & -1.0168 \\
\hline $\mathrm{LA} / \mathrm{TA}$ & -0.8006 & -1.5069 & -1.5485 & -1.5900 & -0.9114 & -0.2327 & 0.0720 & 0.3767 & -0.2465 & -0.8698 \\
\hline $\mathrm{TL} / \mathrm{D}$ & -0.3927 & -0.3358 & -0.1590 & 0.0557 & 0.2009 & 0.2951 & 0.4644 & 0.3984 & 0.2985 & 0.7021 \\
\hline ROA & 0.0314 & 0.1147 & 0.5168 & 0.9189 & 0.3376 & -0.2436 & -0.2915 & -0.3395 & -0.2749 & -0.2103 \\
\hline NIM & 0.9692 & 0.8664 & -0.1182 & -1.1027 & -0.8716 & -0.6404 & 0.2072 & 1.0548 & 0.8493 & 0.6438 \\
\hline $\mathrm{NIE} / \mathrm{GI}$ & -0.2091 & -0.0208 & 0.6590 & 1.4415 & 0.3711 & -0.5116 & -0.1806 & 0.1751 & 0.9728 & 1.9107 \\
\hline $\begin{array}{l}\text { 2. Banking } \\
\text { vulnerability } \\
\text { index }\end{array}$ & & & & & & & & & & \\
\hline $\mathrm{CAB} / \mathrm{GDP}$ & -0.2719 & -0.6924 & -0.5209 & -0.9996 & -1.5254 & -0.9538 & -0.8727 & -0.7384 & -0.4752 & -0.8647 \\
\hline $\mathrm{EA} / \mathrm{TA}$ & 0.6652 & 0.6428 & 0.1233 & -0.3157 & -0.4215 & -1.5938 & -2.3419 & -2.0530 & -1.3754 & -0.4852 \\
\hline FCA/FCL & -0.5726 & -0.6487 & -0.9201 & -1.2016 & -1.3089 & -1.5371 & -1.6369 & -1.4615 & -1.2494 & -1.3029 \\
\hline $\mathrm{DC} / \mathrm{GDP}$ & 0.6702 & 0.2740 & 0.3201 & 0.2432 & -1.8632 & -1.9578 & -1.9038 & -1.8296 & -1.7138 & -1.8069 \\
\hline INF & 1.5495 & 1.2634 & 1.1605 & 1.3847 & 1.0419 & 0.6411 & 0.5167 & 0.4388 & -0.7923 & -1.6142 \\
\hline GDPR & 0.3296 & 0.4646 & 0.3352 & 0.2185 & -0.5928 & -1.2522 & -1.0516 & -1.3515 & -2.3649 & -3.0616 \\
\hline $\begin{array}{l}\text { 3. World } \\
\text { economic climate } \\
\text { index }\end{array}$ & & & & & & & & & & \\
\hline GDPRUS & 0.2023 & 0.6149 & 0.8503 & 0.6377 & 1.0666 & 0.8917 & 0.5093 & 0.3222 & 0.1644 & 0.0101 \\
\hline GDPRCH & -0.8385 & -0.7615 & -1.0692 & -0.9923 & -1.1462 & -1.1462 & -1.2231 & -1.3000 & -1.3769 & -1.3769 \\
\hline
\end{tabular}

Source: Author's computation

Table 5. Statistical normalization process of BIFSI

\begin{tabular}{lllll}
\hline PERIOD & BSI & BVI & WECI & BIFSI $=($ BSI+BVI+WECI $)$ \\
\hline 2008Q1 & 7.7070 & 5.1827 & 0.8551 & 4.5816 \\
\hline 2008Q2 & 8.0688 & 4.5569 & 0.8691 & 4.4983 \\
\hline 2008Q3 & 5.4771 & 3.5858 & 0.1941 & 3.0857 \\
\hline 2008Q4 & 4.3416 & 2.8491 & -1.4615 & 1.9097 \\
\hline 2009Q1 & 2.9629 & 2.8560 & -1.9721 & 1.2823 \\
\hline 2009Q2 & 1.6337 & 2.7320 & -2.0555 & 0.7700 \\
\hline 2009Q3 & -3.9009 & 3.1170 & -1.7296 & -0.8378 \\
\hline $\mathbf{2 0 0 9 Q 4}$ & -9.2626 & 3.4052 & 0.0782 & -1.9264 \\
\hline $\mathbf{2 0 1 0 Q 1}$ & -7.9203 & -0.8570 & 1.3389 & -2.4795 \\
\hline $\mathbf{2 0 1 0 Q 2}$ & -6.3430 & -0.6381 & 2.2270 & -1.5847 \\
\hline $\mathbf{2 0 1 0 Q 3}$ & -4.9054 & -0.3331 & 2.7197 & -0.8396 \\
\hline $\mathbf{2 0 1 0 Q 4}$ & -4.6957 & -0.1517 & 2.3101 & -0.8458 \\
\hline $\mathbf{2 0 1 1 Q 1}$ & -5.1286 & 0.4634 & 1.6454 & -1.0066 \\
\hline $\mathbf{2 0 1 1 Q 2}$ & -5.4025 & 2.4316 & 1.2900 & -0.5603 \\
\hline $\mathbf{2 0 1 1 Q 3}$ & -4.6541 & -1.1608 & 0.6619 & -1.7177 \\
\hline $\mathbf{2 0 1 1 Q 4}$ & -2.7000 & 0.9004 & 0.3822 & -0.4724 \\
\hline $\mathbf{2 0 1 2 Q 1}$ & -0.4759 & 0.9863 & 0.4756 & 0.3287 \\
\hline
\end{tabular}




\begin{tabular}{lllll}
\hline $\mathbf{2 0 1 2 Q 2}$ & 3.1521 & -0.0813 & -0.0469 & 1.0080 \\
\hline $\mathbf{2 0 1 2 Q 3}$ & 2.7788 & 2.8842 & -0.1717 & 1.8304 \\
\hline $\mathbf{2 0 1 2 Q 4}$ & 3.1546 & -0.2203 & -0.2892 & 0.8817 \\
\hline $\mathbf{2 0 1 3 Q 1}$ & 1.7596 & 1.6726 & -0.4240 & 1.0027 \\
\hline $\mathbf{2 0 1 3 Q 2}$ & 1.7239 & 1.4050 & -0.7986 & 0.7768 \\
\hline $\mathbf{2 0 1 3 Q 3}$ & 0.9641 & 1.4907 & -0.2272 & 0.7425 \\
\hline $\mathbf{2 0 1 3 Q 4}$ & 1.0373 & 2.0546 & 0.1209 & 1.0709 \\
\hline $\mathbf{2 0 1 4 Q 1}$ & 1.5500 & 2.3699 & -0.6362 & 1.0946 \\
\hline $\mathbf{2 0 1 4 Q 2}$ & 1.0069 & 1.3038 & -0.1466 & 0.7214 \\
\hline $\mathbf{2 0 1 4 Q 3}$ & 1.8765 & 0.4981 & -0.2189 & 0.7186 \\
\hline $\mathbf{2 0 1 4 Q 4}$ & 3.0528 & -0.6705 & -0.3546 & 0.6759 \\
\hline $\mathbf{2 0 1 5 Q 1}$ & 0.7662 & -4.6700 & -0.0795 & -1.3277 \\
\hline $\mathbf{2 0 1 5 Q 2}$ & -0.6423 & -6.6536 & -0.2545 & -2.5168 \\
\hline $\mathbf{2 0 1 5 Q 3}$ & 0.6760 & -7.2901 & -0.7138 & -2.4426 \\
\hline $\mathbf{2 0 1 5 Q 4}$ & 1.8106 & -6.9953 & -0.9778 & -2.0542 \\
\hline $\mathbf{2 0 1 6 Q 1}$ & 0.2059 & -7.9709 & -1.2125 & -2.9925 \\
\hline $\mathbf{2 0 1 6 Q 2}$ & 0.1611 & -9.1354 & -1.3668 & -3.4470 \\
\hline
\end{tabular}

Source: Author's computation

4.2 Trend in the Aggregate Banking Industry Financial Stability Index

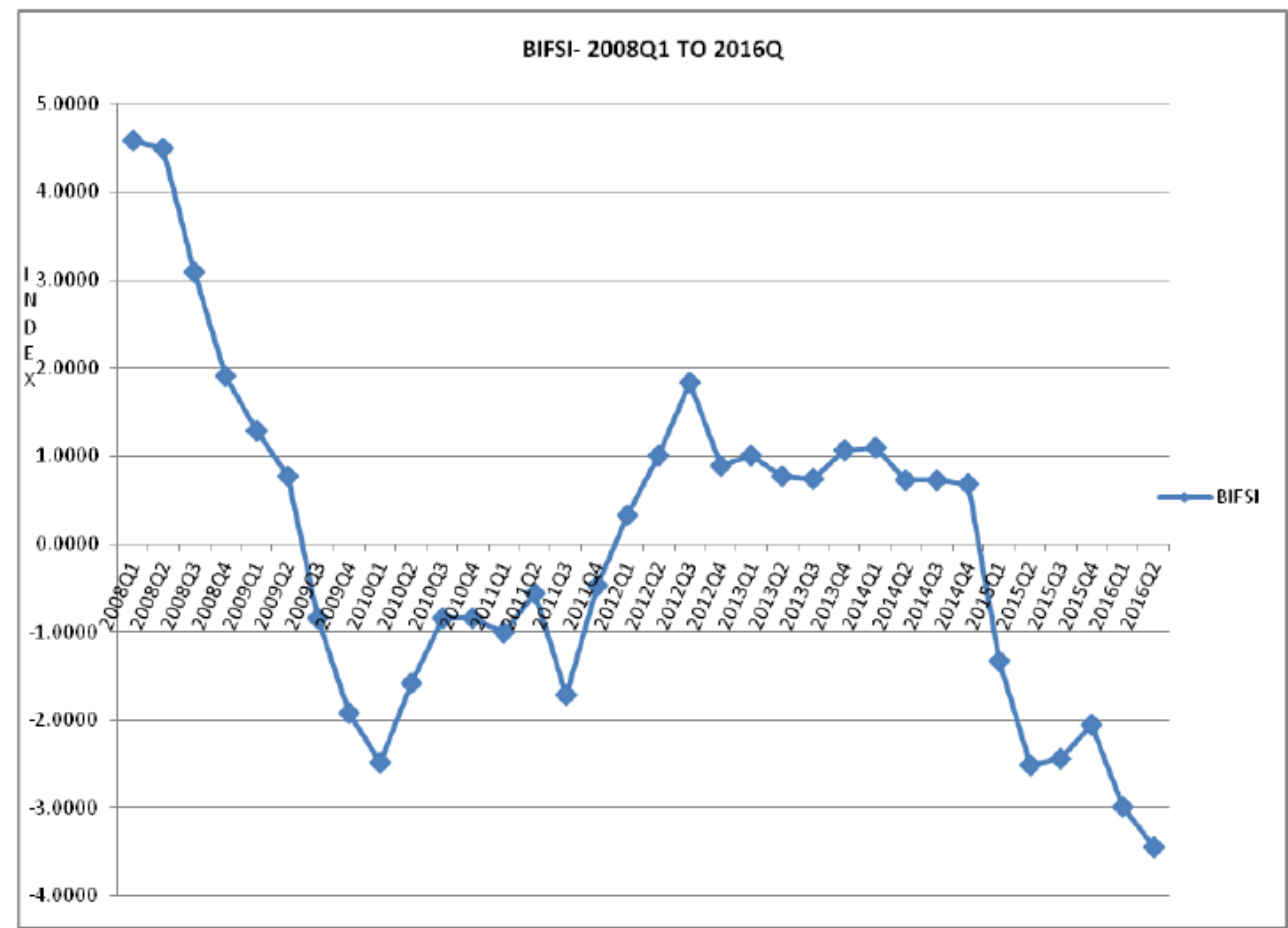

Figure 1. Aggregate banking industry financial stability index (2008Q1-2016Q2)

Source: Author's computation 
Figure 1 shows the trend in the aggregate BIFSI. Using the statistical normalization method, the aggregate BIFSI has a threshold of zero. Consequently, any level above zero depicts above average level and implies that the banking industry is financially stable. The farther away above zero, the more stable is the industry. Conversely, any level below zero depicts financial instability in the banking industry. The farther away below zero the index lies, the higher the degree of financial instability.

The trend in Figure 1 shows that in some periods, there was financial stability in the banking industry while in some other periods, the industry witnessed financial instability. Specifically, the banking industry experienced financial stability firstly from 2008Q1 to 2009Q2 but from 2009Q3 to 2011Q4 it experienced financial instability. From 2012Q1, the industry bounced back to the path of financial stability up to the end of 2014. Between 2015 and 2016, the industry witnessed financial instability.

From the beginning of 2008, it appeared the global financial crises had not largely impacted the banking industry plausibly due to the banking consolidation exercise that was introduced by the CBN in 2005. However, with serious signs of imminent financial instability, the CBN conducted a comprehensive banking audit in 2009. This audit which showed that many of the banks had capital adequacy and liquidity problems, is well depicted in the below average trend of the BIFSI as shown in figure 1 . The 2009 post audit injection of $¥ 620$ billion into the banking industry by way of bail-out funds to eight distressed banks, did not immediately resolve the financial stability problem due to lags in monetary policy effectiveness (CBN, 2009; Sanusi, 2010). Similarly, Due to the high volume of bad loans in the banking industry, the Assets Management Corporation of Nigeria (AMCON) was set up in 2010 to acquire the qualifying non-performing loans of DMBs. Banking supervision and risk based audit were also strengthened by both the CBN and the NDIC. These measures engendered the return of financial stability in 4th quarter of 2011.

Between 2012Q1 and 2014Q4, financial stability remained in the industry owing to several reforms and macro-prudential policies adopted by the CBN. These include increased supervision, revised capital adequacy, liquidity and assets quality ratios. For instance, in 2014 the CBN designated 8 banks as Systemically Important Banks (SIBs) and required them to maintain liquidity ratio of 5\% above industry standard and CAR of $15 \%$ out of which Tier 2 capital should not constitute more than $25 \%$ of the qualifying capital (CBN, 2014). The CAR for DMBs in Nigeria currently set at $10 \%$ for national/regional banks and $15 \%$ for banks that have international banking license (CBN, 2016).

From 2015, the trend in BIFSI shows a return of financial instability. This could largely be attributed to the current economic downturn experienced by the country owing to slump in oil prices and declining government revenue. This has culminated into economic recession in the country and build-up of NPLs in the banking industry, especially in banks with credit exposures in the oil and gas sector. Furthermore, the current persistent high inflation rate also drags the BIFSI into the region of instability. However, it is believed that with appropriate policy measures by the government including diversification of the economic mainstay of the nation, the banking industry will be geared towards the part of financial stability. 


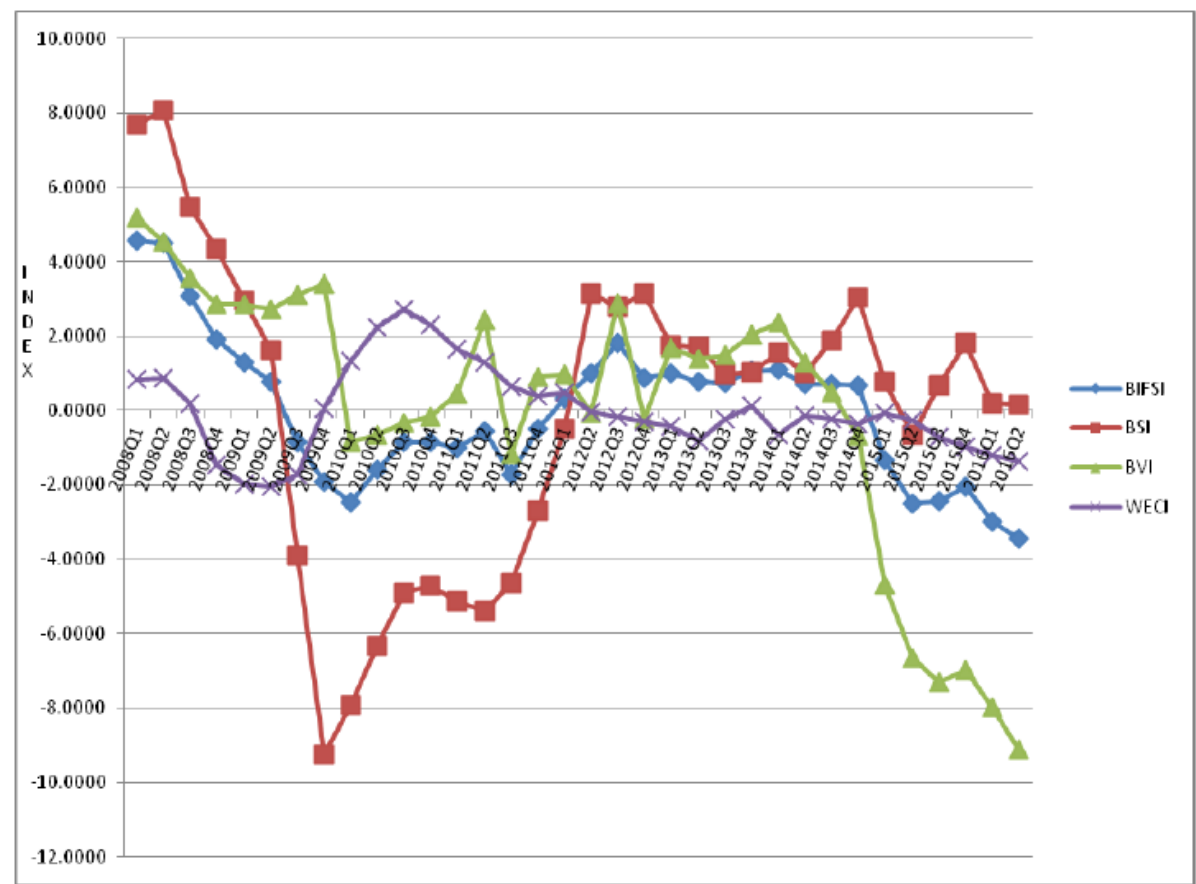

Figure 2. Aggregate banking industry financial stability index and its sub-constituents (2008Q1-2016Q2)

Source: Author's computation

Figure 2 above shows the interaction between the BIFSI and its components. It is interesting to note that the BIFSI lies in the middle of its constituents (BSI, BVI and WECI) meaning that it a good representation of them. All the four curves oscillate over the period; lying below the threshold, zero, in some years and above the threshold in other years. This means that there was financial instability in some years, while there was financial stability in other years.

\subsection{Presentation and Analysis of Econometric Results}

The Augmented Dicky-Fuller (ADF) and the Phillips-Perron (PP) tests were carried out to establish the stochastic behavior of the data employed for this study. The result shows that all the variables are stationary at the first difference. This means that the variables are integrated at order one, I (1). This is shown in table 6 below:

Table 6. Summary of unit root test result

\begin{tabular}{llllll}
\hline \multicolumn{7}{c}{ ADF Test } & \multicolumn{2}{c}{ PP Test } \\
\hline Variable & Level & 1st difference & Level & 1st difference & Order of integration \\
\hline BIFSI & -1.810424 & $-4.051945^{*}$ & -1.92414 & $-4.051945^{*}$ & $\mathrm{I}(1)$ \\
\hline MPR & -0.903741 & $-4.377307^{*}$ & -1.20414 & $-4.458869^{*}$ & $\mathrm{I}(1)$ \\
\hline TBR & -1.685447 & $-4.813317^{*}$ & -1.762243 & $-4.712009^{*}$ & $\mathrm{I}(1)$ \\
\hline EXR & 2.250801 & $-3.172309^{*}$ & 0.352172 & $-3.172309^{*}$ & $\mathrm{I}(1)$ \\
\hline LNGFCF & -1.373743 & $-7.365515^{*}$ & -2.01731 & $-6.543275^{*}$ & $\mathrm{I}(1)$ \\
\hline
\end{tabular}

Note: $5 \%$ critical value for the test is $-2.95 ; *$ implies variable is significant at $5 \%$

Source: Author's computation. 
Table 7. Summary of cointegration test result (trace statistic)

\begin{tabular}{lllll}
\hline Hypothesized Noof CE(s) & Eigenvalue & Trace Statistic & $\mathbf{5 \%}$ Critical Value & $\mathbf{1 \%}$ Critical Value \\
\hline None* & 0.802178 & 100.7995 & $69.81889^{* *}$ & $77.81884^{*}$ \\
\hline Atmost ${ }^{*}$ & 0.625628 & 50.56751 & $47.85613^{* *}$ & 54.68150 \\
\hline Atmost 2 & 0.411816 & 20.10982 & 29.79707 & 35.45817 \\
\hline Atmost 3 & 0.110431 & 3.657625 & 15.49471 & 19.93711 \\
\hline Atmost 4 & 0.000969 & 0.030054 & 3.841466 & 6.634897 \\
\hline
\end{tabular}

Note: *,* Implies statistical significance at the $1 \%$ and $5 \%$ levels, respectively.

Source: Author's computation

Table 8. Summary of cointegration test result (Max-Eigen statistic)

\begin{tabular}{lllll}
\hline Hypothesized Noof CE(s) & Eigenvalue & Max-Eigen Statistic & $\mathbf{5 \%}$ Critical Value & 1\% Critical Value \\
\hline None* & 0.802178 & 50.23195 & $33.87687^{* *}$ & $39.37013^{*}$ \\
\hline Atmost 1* & 0.625628 & 30.45769 & $27.58434^{* *}$ & 32.71527 \\
\hline Atmost 2 & 0.411816 & 16.45220 & 21.13162 & 25.86121 \\
\hline Atmost 3 & 0.110431 & 3.627572 & 14.26460 & 18.52001 \\
\hline Atmost 4 & 0.000969 & 0.030054 & 3.841466 & 6.634897
\end{tabular}

Note: $* * *$ Implies statistical significance at the $1 \%$ and $5 \%$ levels, respectively.

Source: Author's computation

The cointegration test seeks to determine whether or not there exists a long run equilibrium relationship among the variables included in the model. The result of the Johansen cointegration test result is shown in the tables 7 and 8 above. The result of the cointegration test indicates that there is one cointegrating equation respectively, for both the trace and the Max-Eigen statistics at the 1\% level of significance. However, at the 5\% levels of significance, there are two cointegrating equation respectively, for both the Trace statistic and Max-Eigen statistic. Therefore, it was concluded that there exists a long run equilibrium relationship among the variables. Consequently, ECM was employed to estimate the relationship.

The parsimonious ECM results were obtained by removing the variables that were not statistically significant from the over-parameterized ECM results. Monetary policy rate (MPR) which is the key monetary policy variable was discovered to be statistically insignificant in the over-parameterized model. However, given that is it a key monetary policy variable, it was included in the parsimonious model. Two period lag was employed, based on the optimal lag length selection criteria. The result of the parsimonious ECM and the associated model diagnostic test results are depicted in the tables 9 and 10 respectively below:

Table 9. Parsimonious error correction model (ECM)

\begin{tabular}{lllll}
\hline Dependent variable: BIFSI & & & & \\
\hline Variable & Coefficient & Std. Error & t-Statistic & Prob. \\
\hline $\mathrm{C}$ & 0.104366 & 0.116614 & 0.894972 & 0.3809 \\
\hline $\mathrm{D}(\mathrm{MPR})$ & -0.077507 & 0.127764 & -0.606636 & 0.5506 \\
\hline $\mathrm{D}(\mathrm{MPR}(-1))$ & 0.096186 & 0.112472 & 0.855205 & 0.4021 \\
\hline $\mathrm{D}(\mathrm{MPR}(-2))$ & 0.016779 & 0.120376 & 0.139386 & 0.8905 \\
\hline $\mathrm{D}(\mathrm{TBR})$ & 0.099874 & 0.053112 & 1.880431 & 0.0740 \\
\hline $\mathrm{D}(\mathrm{EXR})$ & -0.042043 & 0.011200 & -3.753766 & 0.0012 \\
\hline
\end{tabular}




\begin{tabular}{lllll}
\hline $\mathrm{D}(\mathrm{EXR}(-2))$ & -0.062803 & 0.018095 & -3.470785 & 0.0023 \\
\hline $\mathrm{D}($ LNGFCF) & -1.811223 & 0.580438 & -3.120444 & 0.0052 \\
\hline $\mathrm{D}(\mathrm{LNGFCF}(-2))$ & 0.963787 & 0.509265 & 1.892507 & 0.0723 \\
\hline $\mathrm{ECM}(-1)$ & -0.665377 & 0.137640 & -4.834181 & 0.0001 \\
\hline R-squared & 0.771327 & Mean dependent var & -0.210733 \\
\hline Adjusted R-squared & 0.673325 & S.D. dependent var & 0.793252 \\
\hline S.E. of regression & 0.453387 & Akaike info criterion & 1.511555 \\
\hline Sum squared resid & 4.316756 & Schwarz criterion & 1.974132 \\
\hline Log likelihood & -13.42911 & Hannan-Quinn criter. & 1.662344 \\
\hline F-statistic & 7.870480 & Durbin-Watson stat & 2.191552 \\
\hline Prob(F-statistic) & 0.000052 & &
\end{tabular}

Source: Author's computation

Table 10. Model diagnostic test result

\begin{tabular}{lc}
\hline Jarque-bera: 0.20 & Probability: 0.90 \\
\hline Breusch-Godfrey serial correlation LM test \\
\hline F statistic: $5.43 \quad$ Probability: 0.07 \\
\hline Heteroskedasticity: White \\
\hline F statistic: $9.44 \quad$ Probability: 0.39 \\
\hline
\end{tabular}

Source: Author's computation

The parsimonious result shows that current MPR, one period lagged MPR and two periods lagged MPR are not statistically significant given that their t-values are individually less than 2 (in absolute value). However, current period TBR is positively related to BIFSI and this is consistent with economic a-priori expectation. This implies that $1 \%$ increase in TBR will result in 9\% increase in BIFSI, all things being equal. Lagged values of TBR were found to be statistically insignificant, hence did not feature in the parsimonious results. Both the current period exchange rate and two period lagged exchange rates have negative relationship with BIFSI. This is consistent with economic a-priori expectation. This implies that $1 \%$ increase in current period exchange rate will result in $4 \%$ decrease in BIFSI. Similarly, $1 \%$ increase in two periods lagged exchange rate will result in $6 \%$ decrease in BIFSI, ceteris paribus.

Furthermore, current period investment (LNGFCF) is negatively related to BIFSI; this is inconsistent with a-priori expectation. However, this could be explained in the light of the financial system fragility hypothesis. The hypothesis opined that during periods of economic boom, increased investment could result in the buildup of financial imbalances that ultimately results in financial instability. On the other hand, two periods lagged investment is positively related to BIFSI and this is consistent with economic a-priori expectation. This implies that a $1 \%$ increase in two periods lagged investment will result in 0.96 unit increase in BIFSI.

The result also shows that EXR, EXR $\mathrm{E}_{\mathrm{t}-2}$, and LNGFCF are statistically significant, at the 5\% level of significance. This is because the absolute values of their respective t-values are each greater than 2 (using the rule of thumb). However, TBR and $\mathrm{LNGFCF}_{\mathrm{t}-2}$ are statistically significant at the $10 \%$ level of significance. The coefficient of the error correction term has the right negative sign and it is statistically significant at the $5 \%$ level of significance. This shows that long run disequilibrium in the previous period is corrected by the system quarterly at a speed of 66.54 percent. The adjusted $\mathrm{R}^{2}$ indicates that about $67 \%$ of the variation in BIFSI is explained by the model. This implies that the model has a good fit and a high explanatory power. The F-statistic shows that the overall model is statistically significant given that its p-value is less than $5 \%$.

The result of the normality test shows that the residuals were normally distributed. The serial correlation test indicates that the residuals were not serially correlated, and the result of the heteroskedasticity test shows the 
presence of homoscedasticity. For the three tests, these decisions were made because the p-values are individually greater than 5\%. This is shown in table 10 above. Furthermore, the results of the CUSUM and CUSUM of square tests show that the parameters of the model are stable (given that the blue lines are between the red lines in the two tests respectively).

This study discovered mixed results regarding the effectiveness of monetary policy in ensuring financial stability. This is because not all the policy variables were statistically significant in influencing financial stability. MPR which is a key policy variable and a bench mark rate was found to be statistically insignificant. This means that monetary policy rate will be ineffective if used by the $\mathrm{CBN}$ to influence financial stability in the banking industry. This result is however, contrary to the Keynesian monetary theory which posited that interest rate is the principal medium for monetary policy transmission. The ineffectiveness of monetary policy rate in ensuring financial stability in the banking industry in Nigeria could be ascribed to the underdeveloped nature of the Nigerian money market.

Current period TBR was discovered to have the correct sign and was statistically significant. This means that the CBN exerts strong influence on financial stability in the banking industry through the activities of the OMO in the current period. Hence, by buying or selling treasury bills in the money market, the CBN can effectively increase or reduce liquidity in the banking industry so as to ensure financial stability in the banking industry in Nigeria. This result is in line with the Keynesian monetary transmission mechanism and it is also supported by Graeve et al (2008).

Exchange rate was discovered to have the correct sign and was statistically significant both at the current period and two period lagged values. This shows that depreciation in the value of the naira against the dollar has detrimental effect on financial instability in the banking industry. This result implies that the fall in value of the Naira in relation to other major currencies has adverse effect on financial stability in the banking industry. Furthermore, the result is in line with the studies by Mishkin (1995) and Taylor (1995). These studies held that monetary transmission through exchange rate is more effective under floating exchange rate regime.

Previous period investment was discovered to have a significant positive effect on financial stability in the banking industry. However, current period investment has a significant negative effect. Hence, high investment rate in current period could lead to buildup of financial imbalances which could impinge on financial stability in the banking industry. This implies that although previous period investment has salutary effects on financial stability, in current periods (especially during periods of economic boom), high investment could lead to reckless spending by economic agents which could cause banks to venture into granting unsecured and poorly secured loans resulting in bad loans. The high loan default rate will ultimately lead to financial instability. This result is in tune with the financial fragility hypothesis.

The study discovered long run relationship between monetary policy and financial stability in the banking industry. The speed of adjustment to long run equilibrium was $66.54 \%$. This means that previous period's disequilibrium is corrected by the system at the speed of $66.54 \%$ quarterly.

\section{Conclusion}

The study examined the effect of monetary policy on financial stability in the Nigerian banking industry for the period 2008Q1 to 2016Q2. The study employed econometric method in its investigation. To represent financial stability in the Nigerian banking industry, a banking industry financial stability index (BIFSI) was constructed using the financial stability indicators specified by IMF (2006). MPR, TBR and EXR were used to represent monetary policy, while investment (GFCF) was used as control variable in line with the relevant theories.

The constructed BIFSI was analyzed so as to examine the trend over time. The trend showed mixed outcome implying that the Nigerian banking industry was financially stable in some years while there was financial instability in most other years. The result of the econometric analysis showed that, although, there exists a significant long run equilibrium relationship between monetary policy and financial stability in the banking industry, the impact of the former on the later is weak. This was evidenced by the statistical insignificance of some key monetary policy variables like current period MPR, past periods MPR, past periods TBR etc. Therefore, this study concludes that monetary policy has sparsely impacted financial stability in the banking industry in Nigeria. However, open market operation and exchange rate channels are more effective channels of transmitting monetary policy to financial stability in the banking industry, than monetary policy rate. It is therefore believed that a combination of monetary policy with other relevant policies such as the macro-prudential policy could help in ensuring financial stability in the banking industry in Nigeria.

Based on the foregoing it is recommended that deliberate efforts should be made by the CBN to moderate the MPR and to bridge the gap between the MPR and other interest rates such as lending and deposit rates. Moderate lending 
rates will reduce loan repayment burden and hence reduce the volume of bad loans which impinge financial stability. Open market operations should be encouraged so as to regulate the liquidity trend in the banking industry. This will ensure that excess liquidity does not generate financial instability in the banking industry. Volatility of the exchange rate and pressure on the demand side of the foreign exchange market should be discouraged through appropriate policies such as high tariffs on ostentatious commodity imports and abolition of multiple foreign exchange market (abolition of the bureaux de change and the parallel market).

Although this study is very promising in the depth of its results, it is pertinent to state that the study faced some limitations such as the use of retrospective indicators, exclusion of qualitative factors and the use of quarterly data. This study opens opportunities for future extensions. First, it would be germane to delve into the area of macro-prudential regulation of the CBN and determine whether this has improved the financial stability standing of Nigerian banks. Secondly, the use of annual data or higher frequency data such as monthly data could provide differing results. Lastly, cross country studies which compare the relationship between monetary policy and financial stability in the Nigerian banking industry with that of other African countries such as Kenya, Ghana and South Africa would provide an insight into how outcomes differ amongst similar economies.

\section{References}

Abiola, A., \& Okudua, H. (2008). The role of the Nigerian stock market in achieving vision 2020. Journal of Banking, Finance and Economics, 2(1).

Adenuga, A. O., \& Omotosho, S. O. (2014). Financial depth, financial access and economic growth in Nigeria. Journal of Monetary and Economic Integration, 12(2), 121-137.

Adeyemi, B. (2011) Bank failure in Nigeria: A consequence of capital inadequacy, lack of transparency and non-performing loans?. Banks and Bank Systems, 6(1).

Ajayi, M. (2007). Monetary policy transmission mechanism in Nigeria. Central Bank of Nigeria Economic and Financial Review, 45.

Ali, G. (2015). Cointegration VAR and VECM and ARIMAX econometric approaches for water quality variates. Journal of Statistical and Econometric Methods, 4(1), 1-38.

Allen, F., Babus, A., \& Carletti, E. (2009). Financial crises: Theory and evidence. Social Science Research Network. https://doi.org/10.2139/ssrn.1422715

Alpanda, S., \& Zubarry, S. (2014). Addressing household indebtedness: Monetary, fiscal and macroprudential policy. Bank of Canada Working Papers, 14-58.

Altaee, H. H. A., Talo, I. M. A., \& Adam, M. H. M (2013). Testing the financial stability of banks in GCC countries: Pre and post financial crisis. International Journal of Business and Social Research (IJBSR), 3(4), 93-105.

Altunbas, Y., Gambacorta, L., \& Marqués-Ibáñez, D. (2010). Does monetary policy affect bank risk taking?. BIS Working Paper No. 298. https://doi.org/10.2139/ssrn.1577075

Amadeo, K. (2013). An introduction to the financial markets, definition, types and function. Retrieved from http://useconomy.about.com/od/themarkets/a/capital_markets.htm

Amidu, M., \& Wolfe, S. (2013). Does bank competition and diversification lead to greater stability?: Evidence from emerging markets. Review of Development Finance, 3(1), 152-166. https://doi.org/10.1016/j.rdf.2013.08.002

Anyanwu, J. C. (1993). Monetary Policy Management in Nigeria. Enugu: Ozone.

Arimi, R. S. (2014). ARDL bounds testing approach to cointegration: A re-examination of the augumented Fisher hypothesis in an open economy. Asian Journal of Economic Modelling, 2(2), 103-114.

Beck, T., \& Levine, R. (2002). Stock market, banks and growth: Panel evidence. NBER Working Paper series No. 9082. Cambridge, Mass: National Bureau of Economic Research. https://doi.org/10.3386/w9082

Bhide, A. (1993). The hidden cost of stock market liquidity. Journal of Financial Economics, 34(1), 1-51.

Borio, C. (2014). Monetary policy and financial Stability: What role in prevention and recovery? Bank for International Settlement Working Papers, 440(1). https://doi.org/10.24149/gwp203

Central Bank of Nigeria. (2009). Code of corporate governance for banks.

Central Bank of Nigeria. (2010). Annual reports.

Central Bank of Nigeria. (2012). National financial inclusion strategy: Summary report. 
Central Bank of Nigeria. (2014). Statistical bulletin.

Central Bank of Nigeria. (2015). Statistical bulletin.

Central Bank of Nigeria. (2016). Statistical bulletin.

Central Bank of Nigeria. (n.d.). Financial stability reports, various issues.

Cerutti, E., Claessens, S., \& Laeven, L. (2015). The use and effectiveness of macroprudential policies: New evidence. IMF Working Papers, 15(61).

Chiejine, C. (2010). Corporate governance in the Nigerian banking sector: An ethical analysis of the 2009 regulator intervention and operators' behaviour. M.Sc Thesis, University of Pennsylvania.

Christensen, I., \& Meh, C. (2011). Counter cyclical loan-to-value ratios and monetary policy. Paper presented at the Bank of Canada workshop on Tools for Macroprudential Supervision.

Christian, F., Kristina, H., \& Cunningham, R, (2015). Monetary policy and financial stability: Cross-country evidence. Bank of Canada Staff Working Papers, 15(1).

Chude, N. P., \& Chude, D. I. (2013). Effect of money supply on the stock market returns in Nigeria. Journal of Business and Organisational Development, 5(2).

Cihak, M., \& Hesse, H. (2010). Islamic banks and financial stability: An empirical analysis. Journal of Financial Services Research, 38(3), 95-113. https://doi.org/10.1007/s10693-010-0089-0

Cihak, M., Demirguc-Kunt, A., Feyen, E., \& Levine, R. (2013). Financial development in 205 economies, 1960 to 2010. NBER Working Paper No.18946. https://doi.org/10.3386/w18946

Collard, F., Dallas, H., Diba, B., \& Loisel, O. (2012). Optimal monetary and prudential policies. Banque de France Working Paper No. 413. https://doi.org/10.2139/ssrn.2192467

Congressional Budget Office (CBO). (2009). The troubled asset relief program. Washington D.C, USA. Retrieved from https://www.cbo.gov/sites/default/files/111th-congress-2009-2010/reports/01-16-tarp.pdf

Congressional Research Service (CRS). (2010). The global financial crisis: Analysis and policy implications. Retrieved from https://www.fas.org/sgp/crs/misc/RL34742.pdf

Demirguc-Kunt, A., \& Levine, K. (2001). Financial structure and economic growth: A cross-country comparison of banks, market and development. Cambridge Mass: MIT Press.

Demirguc-Kunt, A., Detragiache, E., \& Tressel, T. (2008). Banking on the principles: Compliance with Basel core principles on bank soundness. Journal of Financial Intermediation, 17(4), 511-42. https://doi.org/10.1016/j.jfi.2007.10.003

Demirguc-Kunt, A., Klapper, L., Singer, D., \& Oudheusden, P. V. (2015). The global findex database 2014: Measuring financial inclusion around the world. World Bank Policy Research Working Paper No. 7255.

Demirguc-Kunt, A., Laeven, L. \& Levine, R. (2004). Regulations, market structure, institutions, and the cost of financial intermediation. Journal of Money, Credit and Banking, 36(30), 593-622. https://doi.org/10.1353/mcb.2004.0045

Dhal, S., Kumar, P., \& Ansari, J. (2011). Financial stability, economic growth, inflation and monetary policy linkages in India: An empirical reflection. Reserve Bank of India Occasional Papers, 32(3).

Dovern, J., Meier, C., \& Vilsmeier, J. (2010). How resilient is the German banking system to macroeconomic shocks?. Journal of Banking \& Finance, 34, 1839-1848. https://doi.org/10.1016/j.jbankfin.2009.12.001

Egbo, O. P. (2012). Universal basis of bank failure: The Nigeria case. Journal of Developing Country Studies, 2(10).

Elegbe, A. (2013). Bank failure and economic development in Nigeria: An empirical approach. British Journal of Economics, Finance and Management Science, 8(1).

Engle, R. F., \& Granger, C. J. (1987). Cointegration and error correction: Representation, estimation and testing. Econometrica, 55, 251-276. https://doi.org/10.2307/1913236

European Central Bank. (2007). Financial stability review. European Central Bank, 5(1). Retrieved from https://www.ecb.europa.eu/pub/pdf/other/financialstabilityreview200712en.pdf?4ea457b0f9ce90962ec70beb3e 961230 
Fernández, A. I., Gonzalez, F., \& Suarez, N. (2014). Banking stability, competition and economic volatility. Foundation of Savings Banks Working Document No. 754.

Frank, J., \& Major, C. (1996). Hostile takeover and the correction of management failure. Journal of Financial Economics, 40, 163-18. https://doi.org/10.1016/0304-405X(95)00840-B

Graeve, D., Kick, T., \& Koetter, M. (2008). Monetary policy and financial (in)stability: An integrated micro-macro approach. Journal of Financial Stability, 2(4), 205-231. https://doi.org/10.1016/j.jfs.2007.09.003

Granger, C. W. J. (1988). Causality, cointegration and control. Journal of Economic Dynamics and Control, 12(3), 551-559. https://doi.org/10.1016/0165-1889(88)90055-3

Granger, C. W. J., \& Newbold, P. (1977). Spurious regression in econometrics. Journal of Econometrics, 2, 111-120. https://doi.org/10.1016/0304-4076(74)90034-7

Granville, B., \& Mallick, S. (2009). Monetary and financial stability in the Euro area: Pro-cyclicality versus trade-off. Journal of International Financial Markets, Institutions and Money, 19(4), 662-674. https://doi.org/10.1016/j.intfin.2008.11.002

Gujarati, D. N., \& Porter, D. C. (2009). Vector Autoregression (VAR). Basic Econometrics. New York, McGraw Hill.

Gurley, J., \& Shaw, E. (1960). Money in a Theory of Finance. Washington, Brookings.

Haug, A. A. (2002). Temporal aggregation and the power of cointegration tests: A monte carlo study. Oxford Bulletin of Economics and Statistics, 64(4), 399-412. https://doi.org/10.1111/1468-0084.00025

Hellwig, M. (1998). Banks, markets, and the allocation of risks in an economy. Journal of Institutional and Theoretical Economics, 154(1), 328-345.

Igoni, P. (2013). Causes of banking crises. CBN Understanding Monetary Policy Series No. 20.

Illing, M., \& Liu, Y. (2003). An index of financial stress for Canada. Bank of Canada Working Papers No. 2003-14.

IMF. (2006). Financial soundness indicators: compilation guide. Washington, D.C: International Monetary Fund.

IMF. (2015). Monetary policy and financial stability. Washington, D.C: International Monetary Fund. https://doi.org/10.5089/9781498344265.007

Jacome, L., \& Nier, E. (2012). Macroprudential policy: Protecting the whole. IMF. Retrieved from http://www.imf.org/external/pubs/ft/fandd/basics/macropru.htm

Johansen, S., \& Juselius, K. (1990). Maximum likelihood estimation and inference on co-integration, with application to the demand for money. Oxford Bulletin of Economics and Statistics, 52, 169-210.

Karin, Z. A., Zaidi, M. A. S., Ismail, M. A., \& Karim, B. A. (2011). Institutions and foreign direct investment (FDI) in Malaysia: Empirical evidence using ARDL model. MPRA Paper 31899, University of Munich, Germany.

Kim, K. (2003). Dollar exchange rate and stock price: Evidence from multivariate cointegration and error correction model. Review of Financial Economics, 12(1), 301-313. https://doi.org/10.1016/S1058-3300(03)00026-0

Kristína, K. (2015): Banking stability index: A cross-country study. Paper presented at the 15th International Conference on Finance and Banking. Praha, Czech Republic.

Kryvstov, O., Molico, M., \& Tomlin, B. (2015). On the nexus of monetary policy and financial stability: Recent developments and research. Bank of Canada Working Paper.

Leeper, M., \& Nason, J. (2015). Bringing financial stability into monetary policy. Sveriges Riksbank Working Paper Series No. 305. https://doi.org/10.2139/ssrn.2635384

Levine, F. (2002). Bank-based or market-based financial system: Which is better? Journal of Financial Intermediation, 11(4), 398-428. https://doi.org/10.1006/jfin.2002.0341

Levine, R. (1998). The legal environment, banks and long-run economic growth. Journal of Money, Credit and Banking, 30, 596-620.

Levine, R. (1999). Law, finance and economic growth. Journal of Financial Intermediation, 8(1), 36-67. https://doi.org/10.1006/jfin.1998.0255

Levine, R. (2005). Finance and growth: Theory and evidence. National Bureau of Economic Research Working Paper No. 10766. Retrieved from http://www.nber.org/papers/w10766 
Levine, R., \& Zervos, S. (1998). Stock markets, banks and economic growth. American Economic Review, 88(1), 537-58.

Maddaloni, A., \& Peydró, J. (2013). Monetary policy, macroprudential policy and banking stability: Evidence from the Euro area. European Central Bank Working Paper Series No. 1560.

Maliszewski, K. (2009). Measuring stability of the polish financial system by means of a synthetic index. Proceedings of the 12th International Conference on Finance and Banking (pp. 364-384). Ostravice, Karviná: Silesian University.

Martin, C., \& Milas, C. (2010). Financial stability and monetary policy. Bath Economic Research Paper, 10(5).

Masron, T. A. (2009). Macroeconomic synchronization of foreign direct investment inflow into ASEAN: Evidence from Malaysian's experiences. International Business Research, 20(3), 11-46. https://doi.org/10.5539/ibr.v2n3p36

Mayuku, G., Ogude, B., Ibeh, S., \& Oluwafase, B. (2012). An appraisal of the impact of bank distress on Nigerian economy, (1986-2010): An empirical investigation. International Journal of Business and Social Science, 3(24).

Mbutor, M. O. (2007). The lending channel of monetary policy transmission in Nigeria, vector auto regressive (VAR) verification. CBN Economic and Financial Review, 45(1), 57-78.

Mensi, S., \& Labidi, W. (2015). The effect of diversification of banking products on the relationship between market power and financial stability. American Journal of Economics and Business Administration, 7(4), 185-193. https://doi.org/10.3844/ajebasp.2015.185.193

Merton, R. C., \& Bodie, Z. (1995). A conceptual framework for analyzing the financial Environment in the global financial system: A functional perspective. USA: Harvard Business School Press

Milton, F. (1956). The Quantity Theory of Money - A Restatement: Reprinted from Studies in the Quantity Theory of Money. University of Chicago Press.

Minsky, H. P. (1972). Financial instability revisited: The economics of disaster. In Reappraisal of the federal reserve discount mechanism, board of governors, federal reserve system (Reprinted as Ch. 6 in Minsky (1982)).

Minsky, H. P. (1982). Can 'it' happen again? Essays on instability and finance. Armonk, NY: ME Sharpe.

Minsky, H. P. (1986). Stabilizing an unstable economy. Yale University Press.

Mishkin, F. S. (1995). Symposium on the monetary transmission mechanism. Journal of Economic Perspective, 9, 3-10. https://doi.org/10.1257/jep.9.4.3

Morgan, P., \& Pontines, V. (2014). Financial stability and financial inclusion. Asian Development Bank Institute Working Paper No. 488. https://doi.org/10.2139/ssrn.2464018

Morris, V. C. (2011). Measuring and forecasting financial stability: The composition of an aggregate financial index for Jamica. Business, Finance and Economics in Emerging Economics, 6(2).

Mukhtar, T., \& Rasheed, S. (2010). Testing long run relationship between exports and imports: Evidence from Pakistan. Journal of Economic Cooperation and Development, 31(1), 41-58.

Myint, H. (1980). The economics of the developing countries. London: Hutchinson \& Co.

Narayan, P. K. (2005). The saving and investment nexus for China: Evidence from cointegration tests. Journal of Applied Economics, 37(17), 1979-1990. https://doi.org/10.1080/00036840500278103

Ndebbio, J. E. (2004) Financial deeping, economic growth and development: Evidence from selected sub sahara African countries. African Economic Research Consortium Research Papers No. 142.

Ndugbu, M., \& Okere, P. (2015). Monetary policy and the performance of deposit money banks: The Nigerian experience. European Journal of Business and Management, 7(17).

Ngakosso, A. (2016). Monetary policy and financial stability: A CEMAC zone case study. American Journal of Economics, 6(3), 171-179.

Nicholas, C., \& Isabel, C. (2010). Aggregate financial stability index for an early warning system. Monetary Authority of Macao Research and Statistics Department Paper No. 14.

Nwanne, T. F. I. (2015). Relationship between financial inclusion and economic growth in Nigerian rural dwellers. International Journal of Small Business and Entrepreneurship Research, 3(7), 17-27. 
Nwosu, E. O., Amadi, F. N., \& Mba, P. N. (2012). Bank consolidation and bank risk taking behaviour: A panel study of commercial banks in Nigeria. Research Journal of Finance and Accounting, 3(9), 68-78.

Nzotta, M. S., \& Okereke, J. E. (2009). Financial deepening and economic development of Nigeria: An empirical investigation. Africa Journal of Accounting, Economics, Finance and Banking Research, 5(5).

Obafemi, F. N., \& Ifere, E. O. (2015). Monetary policy transmission mechanism in Nigeria: A FAVAR Approach. International Journal of Economics and Finance, 7(8). https://doi.org/10.5539/ijef.v7n8p229

Ohwofasa, B. O., \& Mayuku, J. G. (2012). Determinants of bank distress and effect on Nigerian economy, 1986-2010: An empirical analysis. European Journal of Humanities and Social Sciences, 17(1).

Oima, D., \& Ojwang, C. (2013). Impact of market-based and bank-based financial structures on economic growth in some selected Ecowas countries. International Journal of Education and Research, 1(2).

Okpala, K. E. (2013). Bank recapitalization and lending behaviour: A pragmatic evidence from Nigerian banking sector. Journal of Finance and Investment Analysis, 2(4), 185-195.

Okpara, G. C. (2010). Monetary policy and stock market returns: Evidence from Nigeria. J. Economics, 1(1), 13-21. https://doi.org/10.1080/09765239.2010.11884920

Okpara, G. C. (2011). Financial inclusion and financial stability: A Toda-Yamamoto casuality approach. ABSU Journal of Arts, Management, Education, Law and Social Sciences, 1(1), 86-100.

Onafalujo, A. K., \& Eke, P. O. (2015). An empirical analysis of monetary policies on stock price distortion in Nigeria: Implications on real sector. British Journal of Economics, Management and Trade, 5(4), 392-407. https://doi.org/10.9734/BJEMT/2015/13851

Patrick, H. (1966). Financial development and economic growth in underdeveloped countries. Journal of Economic Development and Culture Change, 14(2). https://doi.org/10.1086/450153

Pesaran, M. H., \& Shin, Y. (1997). An autoregressive distributed lag modeling approach to cointegration analysis. Cambridge Working Papers in Economics No. 9514.

Pesaran, M. H., Shin, Y., \& Smith, R. J. (2001). Bounds testing approaches to the analysis of level relationships. Journal of Applied Econometrics, 16(3), 289-326. https://doi.org/10.1002/jae.616

Phillips, P. C. B., \& Perron, P. (1988). Testing for Unit Roots in Time Series Regression. Biometrika, 75, 335-346. https://doi.org/10.1093/biomet/75.2.335

Proshare. (2009). CBN - 100 days after a review of the post August 14, 2009 policies on investors. The Analyst.

Rejan, R, G., \& Zingales, L. (1998). Which capitalism? Lesson from east Asian crisis. Journal of Applied Corporate Finance, 11, 40-45. https://doi.org/10.1111/j.1745-6622.1998.tb00501.x

Samuel, M. N., \& Emeka, J. O. (2009). Financial deepening and economic development of Nigeria: An empirical investigation. African Journal of Accounting, Economics, Finance and Banking Research, 5(5).

Sanusi, L. S. (2010). The Nigerian banking industry: What went wrong and the way forward. CBN Governor's Speech, CBN Annual Report (pp. 1-23).

Sanusi, L. S. (2012). Financial inclusion for accelerated micro, small and medium enterprises development: The Nigerian perspective. Paper presented at the 2012 Annual Microfinance and Entrepreneurship Awards.

Schinasi, G. (2004). Defining financial stability. IMF Working Paper WP/04/187, 6(1). https://doi.org/10.5089/9781451859546.001

Sere-Ejembi, A., Udom, I. S., Salihu, A., Atoi, N. V., \& Yaaba, B. N. (2014). Developing banking system stability index for Nigeria. CBN Journal of Applied Statistics, 5(1), 49-76.

Sevensson, L. E. (2015). Monetary policy and financial stability. A Written speech at Financial Liberalization, Innovation, and Stability: International Experience and Relevance for China, the Third Joint Conference, People's Bank of China and International Monetary Fund, Beijing. https://doi.org/10.5089/9781498344265.007

Shaw, E. (1973). Financial deepening in economic development. London: Oxford University Press.

Shitile, T. S. (2013). Macro-prudential regulation. CBN Understanding Monetary Policy Series No. 25.

Sims, C. A. (1980). Macroeconomics and Reality. Econometrica, 48, 1-48. https://doi.org/10.2307/1912017 
Singh, A. (1997). Stock market, financial liberalization and economic development. The Economic Journal, 107(442), 771-782. https://doi.org/10.1111/j.1468-0297.1997.tb00042.x

Smets, F. (2013). Financial stability and monetary policy: How closely interlinked?. Sveriges Riksbank Economic Review.

Soedarmono, W., Machrouh, F., \& Tarazi, A. (2011). Bank market power, economic growth and financial stability: Evidence from Asian banks. Journal of Asian Economics, 22(6), 460-470. https://doi.org/10.1016/j.asieco.2011.08.003

Soludo, C. C. (2004). Consolidating the Nigerian banking industry to meet the development challenges of the 21th century. An Address by the CBN Governor at the Special Meeting of the Bankers Committee in Abuja.

Soyibo, A. (1994). Conceptual and theoretical issues in the study of informal finance. In E. U. Olisadebi \& A. Olu. (Eds.), Conceptual and Methodological Framework for Informal Sector Research in Nigeria. Ibadan: New World Press.

Stein, C. J. (2012). Monetary policy and financial stability regulation. The Quarterly Journal of Economics, National Bureau of Economic Research, 127, 57-95. https://doi.org/10.1093/qje/qjr054

Tabak, M., Laizy, M., \& Cajueiro, D. (2010). Financial stability and monetary policy: The case of Brazil. Banco Central do Brasil, working paper series No. 217.

Taylor, J. B. (1995). The monetary transmission mechanism: An empirical framework. Journal of Economic Perspective, 914, 11-26. https://doi.org/10.1257/jep.9.4.11

Uchendu, A. O. (1996). The transmission of monetary Policy in Nigeria. CBN Economic and Financial Review, 34(2), 600-625.

Umanhonlen, O. F., \& Lawani I. R, (2015). Effect of global financial meltdown on the Nigerian banking industry and economy. Benin City: Scientific \& Academic Press.

Uzoaga, W.O. (1981). Money and banking in Nigeria. Enugu: Fourth Dimension.

Wai, U. T (1980). The role of unorganized financial markets in economic development and formulation of monetary policy. Journal of Savings and Development, 4(4), 259-265.

WAMO. (2009). Financial stability and banking supervision within ECOWAS. Freetown: West African Monetary Agency.

Retrieved

from http://www.amao-wama.org/fr/Publications/rep/Stabilit\%C3\%A9\%20financi\%C3\%A8re/ENG\%20Stabilite\%20 Financiaere\%20final.pdf

Wand, R. (1970). Public interpretation of federal reserve discount rate changes: Evidence of the "announcement Effect". Econometrical, 38, 231-250. https://doi.org/10.2307/1913006

William, R. W. (2009). Should monetary policy "lean or clean"?. Federal reserve bank of Dallas globalization and monetary policy institute working paper NO.34. https://doi.org/10.24149/gwp34

World Bank. (2014). World development report.

World Bank. (2016). Financial stability. Retrieved from http://www.worldbank.org/en/publication/gfdr/background/financial-stability

\section{Appendix}

Appendix 1. Macroeconomic variables

\begin{tabular}{llllll}
\hline PERIOD & BIFSI & MPR & LNGFCF & EXR & TBR \\
\hline $\mathbf{2 0 0 8 Q 1}$ & 4.5816 & 9.50 & 13.1437 & 116.79 & 8.50 \\
\hline $\mathbf{2 0 0 8 Q 2}$ & 4.4983 & 10.25 & 13.0357 & 117.74 & 8.61 \\
\hline $\mathbf{2 0 0 8 Q 3}$ & 3.0857 & 9.75 & 13.2450 & 117.62 & 9.10 \\
\hline $\mathbf{2 0 0 8 Q 4}$ & 1.9097 & 9.75 & 13.1587 & 134.33 & 5.46 \\
\hline $\mathbf{2 0 0 9 Q 1}$ & 1.2823 & 9.75 & 13.4049 & 148.54 & 2.53 \\
\hline
\end{tabular}




\begin{tabular}{llllll}
\hline 2009Q2 & 0.7700 & 8.00 & 13.3889 & 153.25 & 3.32 \\
\hline 2009Q3 & -0.8378 & 6.00 & 13.5265 & 149.80 & 5.27 \\
\hline 2009Q4 & -1.9264 & 6.00 & 13.8010 & 149.80 & 3.77 \\
\hline 2010Q1 & -2.4795 & 6.00 & 14.6346 & 150.08 & 1.04 \\
\hline 2010Q2 & -1.5847 & 6.00 & 14.5475 & 151.28 & 2.29 \\
\hline 2010Q3 & -0.8396 & 6.25 & 14.7811 & 152.62 & 4.91 \\
\hline 2010Q4 & -0.8458 & 6.25 & 14.7119 & 152.63 & 7.47 \\
\hline 2011Q1 & -1.0066 & 7.50 & 14.7734 & 155.21 & 8.27 \\
\hline 2011Q2 & -0.5603 & 8.00 & 14.6570 & 155.65 & 8.35 \\
\hline 2011Q3 & -1.7177 & 9.25 & 14.8501 & 156.70 & 8.49 \\
\hline 2011Q4 & -0.4724 & 12.00 & 14.7078 & 162.17 & 14.23 \\
\hline 2012Q1 & 0.3287 & 12.00 & 14.8406 & 157.72 & 14.51 \\
\hline 2012Q2 & 1.0080 & 12.00 & 14.8162 & 162.33 & 14.08 \\
\hline 2012Q3 & 1.8304 & 12.00 & 14.7074 & 157.78 & 12.75 \\
\hline 2012Q4 & 0.8817 & 12.00 & 14.7982 & 157.33 & 11.77 \\
\hline 2013Q1 & 1.0027 & 12.00 & 14.7525 & 158.38 & 10.17 \\
\hline 2013Q2 & 0.7768 & 12.00 & 14.8976 & 160.02 & 11.60 \\
\hline 2013Q3 & 0.7425 & 12.00 & 14.8606 & 161.96 & 10.91 \\
\hline 2013Q4 & 1.0709 & 12.00 & 14.9569 & 159.05 & 10.97 \\
\hline 2014Q1 & 1.0946 & 12.00 & 14.9792 & 164.62 & 11.92 \\
\hline 2014Q2 & 0.7214 & 12.00 & 15.0928 & 162.82 & 9.98 \\
\hline 2014Q3 & 0.7186 & 12.00 & 14.9641 & 162.93 & 9.75 \\
\hline 2014Q4 & 0.6759 & 13.00 & 15.1113 & 180.33 & 10.80 \\
\hline 2015Q1 & -1.3277 & 13.00 & 15.0980 & 197.07 & 10.77 \\
\hline 2015Q2 & -2.5168 & 13.00 & 15.1365 & 196.92 & 9.95 \\
\hline 2015Q3 & -2.4426 & 13.00 & 14.9861 & 197.00 & 10.36 \\
\hline 2015Q4 & -2.0542 & 11.00 & 15.0784 & 196.99 & 4.57 \\
\hline 2016Q1 & -2.9925 & 12.00 & 15.0319 & 197.00 & 5.53 \\
\hline 2016Q2 & -3.4470 & 12.00 & 15.0481 & 231.76 & 8.32 \\
\hline & & & & & \\
\hline
\end{tabular}

Appendix 2. Cointegration test results

Date: 03/07/17 Time: 13:24

Sample (adjusted): 2008Q4 2016Q2

Included observations: 31 after adjustments

Trend assumption: Linear deterministic trend

Series: BIFSI MPR EXR TBR LNGFCF

Lags interval (in first differences): 1 to 2

Unrestricted Cointegration Rank Test (Trace)

\begin{tabular}{lll}
\hline Hypothesized & Trace & 05
\end{tabular}




\begin{tabular}{lcccc}
\hline No. of CE(s) & Eigenvalue & Statistic & Critical Value & Prob.** \\
\hline None ${ }^{*}$ & 0.802178 & 100.7995 & 69.81889 & 0.0000 \\
\hline At most $1 *$ & 0.625628 & 50.56751 & 47.85613 & 0.0272 \\
\hline At most 2 & 0.411816 & 20.10982 & 29.79707 & 0.4155 \\
\hline At most 3 & 0.110431 & 3.657625 & 15.49471 & 0.9292 \\
\hline At most 4 & 0.000969 & 0.030054 & 3.841466 & 0.8623 \\
\hline
\end{tabular}

Trace test indicates 2 cointegrating eqn(s) at the 0.05 level

* denotes rejection of the hypothesis at the 0.05 level

**MacKinnon-Haug-Michelis (1999) p-values

Unrestricted Cointegration Rank Test (Maximum Eigenvalue)

\begin{tabular}{|c|c|c|c|c|}
\hline Hypothesized & & Max-Eigen & 0.05 & \\
\hline No. of CE(s) & Eigenvalue & Statistic & Critical Value & Prob.** \\
\hline None * & 0.802178 & 50.23195 & 33.87687 & 0.0003 \\
\hline At most $1 *$ & 0.625628 & 30.45769 & 27.58434 & 0.0208 \\
\hline At most 2 & 0.411816 & 16.45220 & 21.13162 & 0.1995 \\
\hline At most 3 & 0.110431 & 3.627572 & 14.26460 & 0.8964 \\
\hline At most 4 & 0.000969 & 0.030054 & 3.841466 & 0.8623 \\
\hline
\end{tabular}

Unrestricted Cointegrating Coefficients (normalized by $b^{\prime * S 11 * b=I): ~}$

\begin{tabular}{lclcc}
\hline BIFSI & MPR & EXR & TBR & LNGFCF \\
\hline-4.650977 & 1.768409 & -0.496808 & 0.209822 & 3.993011 \\
\hline 0.606812 & -1.642197 & 0.073324 & 0.872889 & 1.302126 \\
\hline-0.625299 & 0.009665 & 0.010489 & 0.642532 & -2.800877 \\
\hline-0.449260 & -0.536113 & 0.000909 & 0.311027 & -1.861012 \\
\hline 0.373979 & -0.549250 & 0.159444 & 0.129683 & -2.366235 \\
\hline
\end{tabular}

\begin{tabular}{lccccc}
\hline \multicolumn{7}{l}{ Unrestricted Adjustment Coefficients (alpha): } & & & \\
\hline $\mathrm{D}(\mathrm{BIFSI})$ & 0.411286 & -0.036377 & 0.100404 & -0.046074 & -0.004752 \\
\hline $\mathrm{D}(\mathrm{MPR})$ & 0.204177 & 0.189491 & -0.311088 & 0.043055 & 0.008033 \\
\hline $\mathrm{D}(\mathrm{EXR})$ & -1.236866 & -3.734815 & -1.371921 & -0.110925 & 0.095484 \\
\hline $\mathrm{D}(\mathrm{TBR})$ & 0.636323 & 0.005925 & -0.898831 & 0.140525 & -0.009544 \\
\hline $\mathrm{D}(\mathrm{LNGFCF})$ & -0.033514 & -0.011376 & 0.016123 & 0.038063 & 0.000390 \\
\hline
\end{tabular}

1 Cointegrating Equation(s): $\quad$ Log likelihood $\quad-147.6640$

Normalized cointegrating coefficients (standard error in parentheses)

\begin{tabular}{lllll}
\hline BIFSI & MPR & EXR & TBR & LNGFCF \\
\hline 1.000000 & -0.380223 & 0.106818 & -0.045114 & -0.858532 \\
\hline & $(0.04022)$ & $(0.00369)$ & $(0.02786)$ & $(0.11792)$ \\
\hline
\end{tabular}




\begin{tabular}{lc}
\hline Adjustment coefficients (standard error in parentheses) \\
\hline $\mathrm{D}(\mathrm{BIFSI})$ & -1.912882 \\
\hline & $(0.35524)$ \\
\hline $\mathrm{D}(\mathrm{MPR})$ & -0.949622 \\
\hline & $(0.66297)$ \\
\hline $\mathrm{D}(\mathrm{EXR})$ & 5.752637 \\
\hline & $(6.46960)$ \\
\hline $\mathrm{D}(\mathrm{TBR})$ & -2.959525 \\
\hline & $(1.63030)$ \\
\hline $\mathrm{D}(\mathrm{LNGFCF})$ & 0.155871 \\
\hline & $(0.12800)$ \\
\hline
\end{tabular}

2 Cointegrating Equation(s): $\quad$ Log likelihood $\quad-132.4351$

Normalized cointegrating coefficients (standard error in parentheses)

\begin{tabular}{llccc}
\hline BIFSI & MPR & EXR & TBR & LNGFCF \\
\hline 1.000000 & 0.000000 & 0.104527 & -0.287627 & -1.349637 \\
\hline & & $(0.00745)$ & $(0.02807)$ & $(0.26690)$ \\
\hline 0.000000 & 1.000000 & -0.006026 & -0.637819 & -1.291625 \\
\hline & $(0.01690)$ & $(0.06364)$ & $(0.60506)$ \\
\hline
\end{tabular}

Adjustment coefficients (standard error in parentheses)

\begin{tabular}{lcc}
\hline $\mathrm{D}(\mathrm{BIFSI})$ & -1.934956 & 0.787061 \\
\hline & $(0.35610)$ & $(0.18322)$ \\
\hline $\mathrm{D}(\mathrm{MPR})$ & -0.834636 & 0.049886 \\
\hline & $(0.63674)$ & $(0.32762)$ \\
\hline $\mathrm{D}(\mathrm{EXR})$ & 3.486306 & 3.946017 \\
\hline & $(5.13975)$ & $(2.64452)$ \\
\hline $\mathrm{D}(\mathrm{TBR})$ & -2.955930 & 1.115550 \\
\hline & $(1.64410)$ & $(0.84593)$ \\
\hline $\mathrm{D}($ LNGFCF $)$ & 0.148968 & -0.040584 \\
\hline & $(0.12850)$ & $(0.06612)$ \\
\hline
\end{tabular}

3 Cointegrating Equation(s): $\quad$ Log likelihood $\quad-124.2091$

Normalized cointegrating coefficients (standard error in parentheses)

\begin{tabular}{llccc}
\hline BIFSI & MPR & EXR & TBR & LNGFCF \\
\hline 1.000000 & 0.000000 & 0.000000 & -0.933233 & 3.652130 \\
\hline 0.000000 & & & $(0.18465)$ & $(0.86338)$ \\
\hline & 1.000000 & 0.000000 & -0.600601 & -1.579968 \\
\hline 0.000000 & 0.000000 & 1.000000 & $(0.06375)$ & $(0.29810)$ \\
\hline & & 6.176463 & -47.85152 \\
\hline
\end{tabular}




\begin{tabular}{lccc}
\hline \multicolumn{4}{l}{ Adjustment coefficients (standard error in parentheses) } \\
\hline $\mathrm{D}(\mathrm{BIFSI})$ & -1.997739 & 0.788031 & -0.205944 \\
\hline & $(0.34232)$ & $(0.17459)$ & $(0.03634)$ \\
\hline $\mathrm{D}(\mathrm{MPR})$ & -0.640113 & 0.046879 & -0.090806 \\
\hline & $(0.54644)$ & $(0.27869)$ & $(0.05801)$ \\
\hline $\mathrm{D}(\mathrm{EXR})$ & 4.344167 & 3.932758 & 0.326244 \\
\hline & $(4.96674)$ & $(2.53311)$ & $(0.52723)$ \\
\hline $\mathrm{D}(\mathrm{TBR})$ & -2.393891 & 1.106863 & -0.325124 \\
\hline $\mathrm{D}(\mathrm{LNGFCF})$ & $(1.34128)$ & $(0.68407)$ & $(0.14238)$ \\
\hline & 0.138887 & -0.040429 & 0.015985 \\
\hline
\end{tabular}

4 Cointegrating Equation(s): $\quad$ Log likelihood $\quad-122.3953$

Normalized cointegrating coefficients (standard error in parentheses)

\begin{tabular}{lcccc}
\hline BIFSI & MPR & EXR & TBR & LNGFCF \\
\hline 1.000000 & 0.000000 & 0.000000 & 0.000000 & 5.844287 \\
\hline & & & & $(2.96656)$ \\
\hline 0.000000 & 1.000000 & 0.000000 & 0.000000 & -0.169162 \\
\hline 0.000000 & 0.000000 & 1.000000 & 0.000000 & -62.35998 \\
\hline & & & $(1.96808)$ \\
\hline 0.000000 & 0.000000 & 0.000000 & 1.000000 & $2.348961)$ \\
\hline & & & $(3.27495)$ \\
\hline
\end{tabular}

Adjustment coefficients (standard error in parentheses)

\begin{tabular}{lcccc}
\hline $\mathrm{D}(\mathrm{BIFSI})$ & -1.977039 & 0.812732 & -0.205986 & 0.104726 \\
\hline & $(0.34017)$ & $(0.17692)$ & $(0.03595)$ & $(0.08208)$ \\
\hline $\mathrm{D}(\mathrm{MPR})$ & -0.659456 & 0.023797 & -0.090766 & 0.021753 \\
\hline & $(0.54688)$ & $(0.28444)$ & $(0.05779)$ & $(0.13197)$ \\
\hline $\mathrm{D}(\mathrm{EXR})$ & 4.394001 & 3.992226 & 0.326143 & -4.435603 \\
\hline & $(4.98761)$ & $(2.59409)$ & $(0.52707)$ & $(1.20354)$ \\
\hline $\mathrm{D}(\mathrm{TBR})$ & -2.457024 & 1.031526 & -0.324996 & -0.395135 \\
\hline & $(1.33857)$ & $(0.69620)$ & $(0.14146)$ & $(0.32301)$ \\
\hline $\mathrm{D}($ LNGFCF $)$ & 0.121787 & -0.060834 & 0.016019 & 0.005236 \\
\hline & $(0.12217)$ & $(0.06354)$ & $(0.01291)$ & $(0.02948)$ \\
\hline
\end{tabular}

Date: 03/07/17 Time: 13:27

Sample (adjusted): 2008Q4 2016Q2

Included observations: 31 after adjustments

Trend assumption: Linear deterministic trend

Series: BIFSI MPR EXR TBR LNGFCF 
Lags interval (in first differences): 1 to 2

\begin{tabular}{|c|c|c|c|c|}
\hline \multicolumn{5}{|c|}{ Unrestricted Cointegration Rank Test (Trace) } \\
\hline \multicolumn{2}{|l|}{ Hypothesized } & \multirow{2}{*}{$\begin{array}{l}\text { Trace } \\
\text { Statistic }\end{array}$} & \multicolumn{2}{|l|}{0.01} \\
\hline No. of CE(s) & Eigenvalue & & Critical Value & Prob.** \\
\hline None $*$ & 0.802178 & 100.7995 & 77.81884 & 0.0000 \\
\hline At most 1 & 0.625628 & 50.56751 & 54.68150 & 0.0272 \\
\hline At most 2 & 0.411816 & 20.10982 & 35.45817 & 0.4155 \\
\hline At most 3 & 0.110431 & 3.657625 & 19.93711 & 0.9292 \\
\hline At most 4 & 0.000969 & 0.030054 & 6.634897 & 0.8623 \\
\hline \multicolumn{5}{|c|}{ Trace test indicates 1 cointegrating eqn(s) at the 0.01 level } \\
\hline
\end{tabular}

Unrestricted Cointegration Rank Test (Maximum Eigenvalue)

\begin{tabular}{lcccc}
\hline Hypothesized & \multicolumn{5}{l}{ Max-Eigen } & 0.01 \\
\hline No. of CE(s) & Eigenvalue & Statistic & Critical Value & Prob.** \\
\hline None $*$ & 0.802178 & 50.23195 & 39.37013 & 0.0003 \\
\hline At most 1 & 0.625628 & 30.45769 & 32.71527 & 0.0208 \\
\hline At most 2 & 0.411816 & 16.45220 & 25.86121 & 0.1995 \\
\hline At most 3 & 0.110431 & 3.627572 & 18.52001 & 0.8964 \\
\hline At most 4 & 0.000969 & 0.030054 & 6.634897 & 0.8623 \\
\hline Max-eigenvalue test indicates 1 cointegrating eqn(s) at the 0.01 level \\
\hline$*$ denotes rejection of the hypothesis at the 0.01 level \\
\hline$* *$ MacKinnon-Haug-Michelis (1999) p-values \\
\hline
\end{tabular}

Unrestricted Cointegrating Coefficients (normalized by $\mathrm{b}^{\prime * \mathrm{~S}} 11 * \mathrm{~b}=\mathrm{I}$ ):

\begin{tabular}{lllll}
\hline BIFSI & MPR & EXR & TBR & LNGFCF \\
\hline-4.650977 & 1.768409 & -0.496808 & 0.209822 & 3.993011 \\
\hline 0.606812 & -1.642197 & 0.073324 & 0.872889 & 1.302126 \\
\hline-0.625299 & 0.009665 & 0.010489 & 0.642532 & -2.800877 \\
\hline-0.449260 & -0.536113 & 0.000909 & 0.311027 & -1.861012 \\
\hline 0.373979 & -0.549250 & 0.159444 & 0.129683 & -2.366235 \\
\hline
\end{tabular}

\begin{tabular}{|c|c|c|c|c|c|}
\hline \\
\hline$\overline{\mathrm{D}(\mathrm{BIFSI})}$ & 0.411286 & -0.036377 & \multicolumn{2}{|c|}{ Unrestricted Adjustment Coefficients (alpha): } & -0.004752 \\
\hline$\overline{\mathrm{D}(\mathrm{MPR})}$ & 0.204177 & 0.189491 & -0.311088 & 0.043055 & 0.008033 \\
\hline$\overline{\mathrm{D}(\mathrm{EXR})}$ & -1.236866 & -3.734815 & -1.371921 & -0.110925 & 0.095484 \\
\hline$\overline{\mathrm{D}(\mathrm{TBR})}$ & 0.636323 & 0.005925 & -0.898831 & 0.140525 & -0.009544 \\
\hline$\overline{\mathrm{D}(\mathrm{LNGFCF})}$ & -0.033514 & -0.011376 & 0.016123 & 0.038063 & 0.000390 \\
\hline \multicolumn{2}{|c|}{1 Cointegrating Equation(s): } & Log likelih & -147.6640 & & \\
\hline
\end{tabular}


Normalized cointegrating coefficients (standard error in parentheses)

\begin{tabular}{|c|c|c|c|c|}
\hline BIFSI & MPR & EXR & TBR & LNGFCF \\
\hline \multirow[t]{2}{*}{1.000000} & -0.380223 & 0.106818 & -0.045114 & -0.858532 \\
\hline & $(0.04022)$ & $(0.00369)$ & $(0.02786)$ & (0.11792) \\
\hline \multicolumn{5}{|c|}{ Adjustment coefficients (standard error in parentheses) } \\
\hline \multirow{2}{*}{$\overline{\mathrm{D}(\mathrm{BIFSI})}$} & -1.912882 & & & \\
\hline & $(0.35524)$ & & & \\
\hline \multirow[t]{2}{*}{$\mathrm{D}(\mathrm{MPR})$} & -0.949622 & & & \\
\hline & $(0.66297)$ & & & \\
\hline \multirow[t]{2}{*}{$\overline{\mathrm{D}(\mathrm{EXR})}$} & 5.752637 & & & \\
\hline & $(6.46960)$ & & & \\
\hline \multirow[t]{2}{*}{$\overline{\mathrm{D}(\mathrm{TBR})}$} & -2.959525 & & & \\
\hline & $(1.63030)$ & & & \\
\hline \multirow[t]{2}{*}{ D(LNGFCF) } & 0.155871 & & & \\
\hline & $(0.12800)$ & & & \\
\hline
\end{tabular}

2 Cointegrating Equation(s): $\quad$ Log likelihood $\quad-132.4351$

Normalized cointegrating coefficients (standard error in parentheses)

\begin{tabular}{lcccc}
\hline BIFSI & MPR & EXR & TBR & LNGFCF \\
\hline 1.000000 & 0.000000 & 0.104527 & -0.287627 & -1.349637 \\
\hline & & $(0.00745)$ & $(0.02807)$ & $(0.26690)$ \\
\hline 0.000000 & 1.000000 & -0.006026 & -0.637819 & -1.291625 \\
\hline & $(0.01690)$ & $(0.06364)$ & $(0.60506)$ \\
\hline
\end{tabular}

Adjustment coefficients (standard error in parentheses)

\begin{tabular}{lcc}
\hline $\mathrm{D}(\mathrm{BIFSI})$ & -1.934956 & 0.787061 \\
\hline & $(0.35610)$ & $(0.18322)$ \\
\hline $\mathrm{D}(\mathrm{MPR})$ & -0.834636 & 0.049886 \\
\hline & $(0.63674)$ & $(0.32762)$ \\
\hline $\mathrm{D}(\mathrm{EXR})$ & 3.486306 & 3.946017 \\
\hline & $(5.13975)$ & $(2.64452)$ \\
\hline $\mathrm{D}(\mathrm{TBR})$ & -2.955930 & 1.115550 \\
\hline $\mathrm{D}(\mathrm{LNGFCF})$ & $(1.64410)$ & $(0.84593)$ \\
\hline & 0.148968 & -0.040584 \\
\hline & $(0.12850)$ & $(0.06612)$
\end{tabular}

3 Cointegrating Equation(s): $\quad$ Log likelihood $\quad-124.2091$

Normalized cointegrating coefficients (standard error in parentheses)

\begin{tabular}{lcccc}
\hline BIFSI & MPR & EXR & TBR & LNGFCF \\
\hline 1.000000 & 0.000000 & 0.000000 & -0.933233 & 3.652130 \\
\hline & & $(0.18465)$ & $(0.86338)$ \\
\hline
\end{tabular}




\begin{tabular}{|c|c|c|c|c|}
\hline 0.000000 & 1.000000 & 0.000000 & -0.600601 & -1.579968 \\
\hline & & & $(0.06375)$ & $(0.29810)$ \\
\hline 0.000000 & 0.000000 & 1.000000 & 6.176463 & -47.85152 \\
\hline & & & (1.77934) & (8.31962) \\
\hline
\end{tabular}

\begin{tabular}{lccc}
\hline \multicolumn{3}{l}{ Adjustment coefficients (standard error in parentheses) } \\
\hline $\mathrm{D}(\mathrm{BIFSI})$ & -1.997739 & 0.788031 & -0.205944 \\
\hline $\mathrm{D}(\mathrm{MPR})$ & -0.640113 & 0.046879 & -0.090806 \\
\hline & $(0.54644)$ & $(0.27869)$ & $(0.05801)$ \\
\hline $\mathrm{D}(\mathrm{EXR})$ & 4.344167 & 3.932758 & 0.326244 \\
\hline $\mathrm{D}(\mathrm{TBR})$ & $(4.96674)$ & $(2.53311)$ & $(0.52723)$ \\
\hline & -2.393891 & 1.106863 & -0.325124 \\
\hline $\mathrm{D}(\mathrm{LNGFCF})$ & 0.138887 & -0.040429 & 0.015985 \\
\hline & $(0.12845)$ & $(0.06551)$ & $(0.01364)$ \\
\hline
\end{tabular}

4 Cointegrating Equation(s): $\quad$ Log likelihood $\quad-122.3953$

Normalized cointegrating coefficients (standard error in parentheses)

\begin{tabular}{lllll}
\hline BIFSI & MPR & EXR & TBR & LNGFCF \\
\hline 1.000000 & 0.000000 & 0.000000 & 0.000000 & 5.844287 \\
\hline 0.000000 & 1.000000 & 0.000000 & 0.000000 & -0.169162 \\
\hline \multirow{2}{*}{0.000000} & 0.000000 & 1.000000 & 0.000000 & -62.35998 \\
\hline \multirow{2}{*}{0.000000} & 0.000000 & 0.000000 & 1.000000 & $(1.96808)$ \\
\hline & & & & $(3.2745695)$ \\
\hline
\end{tabular}

\begin{tabular}{lcccc}
\hline \multicolumn{5}{l}{ Adjustment coefficients (standard error in parentheses) } \\
\hline $\mathrm{D}(\mathrm{BIFSI})$ & -1.977039 & 0.812732 & -0.205986 & 0.104726 \\
\hline & $(0.34017)$ & $(0.17692)$ & $(0.03595)$ & $(0.08208)$ \\
\hline $\mathrm{D}(\mathrm{MPR})$ & -0.659456 & 0.023797 & -0.090766 & 0.021753 \\
\hline & $(0.54688)$ & $(0.28444)$ & $(0.05779)$ & $(0.13197)$ \\
\hline $\mathrm{D}(\mathrm{EXR})$ & 4.394001 & 3.992226 & 0.326143 & -4.435603 \\
\hline & $(4.98761)$ & $(2.59409)$ & $(0.52707)$ & $(1.20354)$ \\
\hline $\mathrm{D}(\mathrm{TBR})$ & -2.457024 & 1.031526 & -0.324996 & -0.395135 \\
\hline & $(1.33857)$ & $(0.69620)$ & $(0.14146)$ & $(0.32301)$ \\
\hline $\mathrm{D}(\mathrm{LNGFCF})$ & 0.121787 & -0.060834 & 0.016019 & 0.005236 \\
\hline & $(0.12217)$ & $(0.06354)$ & $(0.01291)$ & $(0.02948)$
\end{tabular}


Appendix 3. Result of over-parameterized model

\begin{tabular}{|c|c|c|c|c|}
\hline \multicolumn{5}{|c|}{ Dependent Variable: D(BIFSI) } \\
\hline \multicolumn{5}{|c|}{ Method: Least Squares } \\
\hline Date: $03 / 07 / 17$ & \multicolumn{4}{|c|}{ Time: $13: 57$} \\
\hline \multicolumn{5}{|c|}{ Sample (adjusted): 2008Q4 2016Q2 } \\
\hline \multicolumn{5}{|c|}{ Included observations: 31 after adjustments } \\
\hline Variable & Coefficient & Std. Error & t-Statistic & Prob. \\
\hline$\overline{\mathrm{C}}$ & 0.138805 & 0.125734 & 1.103957 & 0.2850 \\
\hline D(MPR) & -0.239669 & 0.150059 & -1.597166 & 0.1286 \\
\hline$\overline{\mathrm{D}(\mathrm{MPR}(-1))}$ & 0.236341 & 0.141742 & 1.667401 & 0.1137 \\
\hline$\overline{\mathrm{D}(\mathrm{MPR}(-2))}$ & -0.082833 & 0.130448 & -0.634991 & 0.5339 \\
\hline $\mathrm{D}(\mathrm{EXR})$ & -0.031007 & 0.012235 & -2.534254 & 0.0214 \\
\hline $\mathrm{D}(\mathrm{EXR}(-1))$ & -0.025355 & 0.017782 & -1.425850 & 0.1720 \\
\hline$\overline{\mathrm{D}(\mathrm{EXR}(-2))}$ & -0.056125 & 0.019720 & -2.846093 & 0.0112 \\
\hline$\overline{\mathrm{D}(\mathrm{TBR})}$ & 0.130196 & 0.061760 & 2.108096 & 0.0502 \\
\hline $\mathrm{D}(\mathrm{TBR}(-1))$ & -0.065082 & 0.047418 & -1.372516 & 0.1877 \\
\hline$\overline{\mathrm{D}(\mathrm{TBR}(-2))}$ & 0.108018 & 0.064540 & 1.673641 & 0.1125 \\
\hline$\overline{\mathrm{D}(\mathrm{LNGFCF})}$ & -2.078864 & 0.601428 & -3.456548 & 0.0030 \\
\hline$\overline{\mathrm{D}(\mathrm{LNGFCF}(-1))}$ & -0.280636 & 0.503980 & -0.556839 & 0.5849 \\
\hline D(LNGFCF(-2)) & 1.406211 & 0.540505 & 2.601659 & 0.0186 \\
\hline ECM(-1) & -0.600163 & 0.157011 & -3.822435 & 0.0014 \\
\hline R-squared & 0.828652 & \multicolumn{2}{|c|}{ Mean dependent var } & -0.210733 \\
\hline Adjusted R-squared & 0.697621 & \multicolumn{2}{|c|}{ S.D. dependent var } & 0.793252 \\
\hline S.E. of regression & 0.436201 & \multicolumn{2}{|c|}{ Akaike info criterion } & 1.481025 \\
\hline Sum squared resid & 3.234615 & \multicolumn{2}{|c|}{ Schwarz criterion } & 2.128633 \\
\hline Log likelihood & -8.955895 & \multicolumn{2}{|c|}{ Hannan-Quinn criter. } & 1.692129 \\
\hline F-statistic & 6.324094 & \multicolumn{2}{|c|}{ Durbin-Watson stat } & 2.614848 \\
\hline$\overline{\operatorname{Prob}(F-\text {-statistic })}$ & 0.000314 & & & \\
\hline
\end{tabular}

Appendix 4. Result of normality test

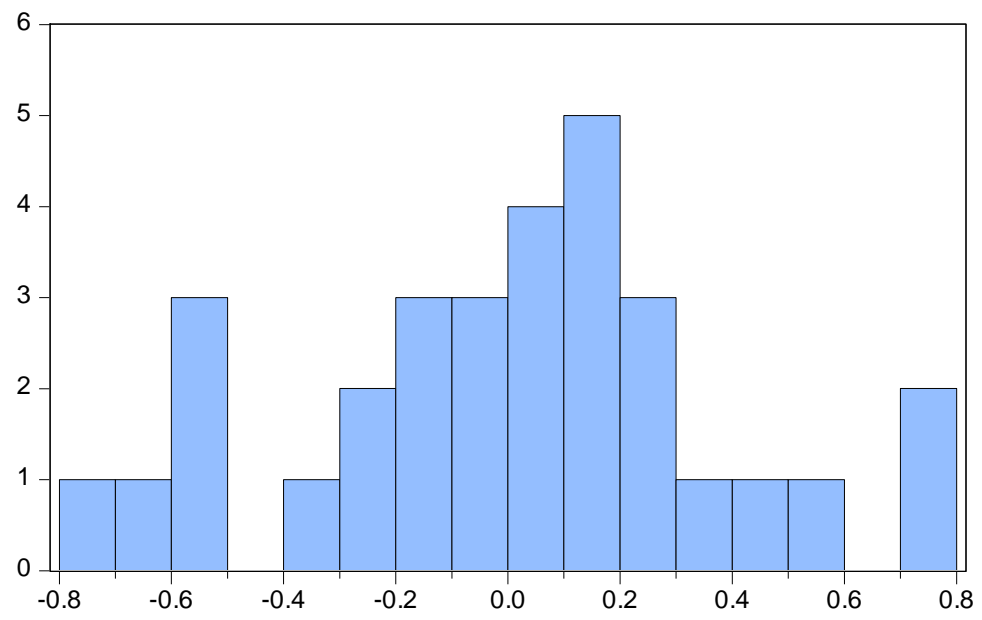

Series: Residuals

Sample 2008Q4 2016Q2

Observations 31

Mean

$-4.75 e-17$

Median $\quad 0.034682$

Maximum $\quad 0.783649$

Minimum $\quad-0.717857$

Std. Dev. $\quad 0.379331$

Skewness $\quad-0.102333$

Kurtosis $\quad 2.658324$

Jarque-Bera $\quad 0.204898$

Probability $\quad 0.902624$ 
Appendix 5. Result of serial correlation test

\begin{tabular}{|c|c|c|c|c|}
\hline \multicolumn{5}{|c|}{ Breusch-Godfrey Serial Correlation LM Test: } \\
\hline F-statistic & 2.017955 & \multicolumn{2}{|c|}{ Prob. $F(2,19)$} & 0.1604 \\
\hline Obs*R-squared & 5.431224 & \multicolumn{2}{|c|}{ Prob. Chi-Square(2) } & 0.0662 \\
\hline \multicolumn{5}{|l|}{ Test Equation: } \\
\hline \multicolumn{5}{|c|}{ Dependent Variable: RESID } \\
\hline \multicolumn{5}{|c|}{ Method: Least Squares } \\
\hline \multicolumn{5}{|c|}{ Date: 04/20/17 Time: 13:47 } \\
\hline \multicolumn{5}{|c|}{ Sample: 2008Q4 2016Q2 } \\
\hline \multicolumn{5}{|c|}{ Included observations: 31} \\
\hline \multicolumn{5}{|c|}{ Presample missing value lagged residuals set to zero. } \\
\hline$\overline{\text { Variable }}$ & Coefficient & Std. Error & t-Statistic & Prob. \\
\hline$\overline{\mathrm{C}}$ & 0.057898 & 0.121229 & 0.477594 & 0.6384 \\
\hline$\overline{\mathrm{D}(\mathrm{MPR})}$ & 0.009552 & 0.136765 & 0.069843 & 0.9450 \\
\hline$\overline{\mathrm{D}(\mathrm{MPR}(-1))}$ & 0.036903 & 0.111745 & 0.330248 & 0.7448 \\
\hline$\overline{\mathrm{D}(\mathrm{MPR}(-2))}$ & -0.011176 & 0.115091 & -0.097108 & 0.9237 \\
\hline$\overline{\mathrm{D}(\mathrm{EXR})}$ & 0.001517 & 0.011073 & 0.137025 & 0.8925 \\
\hline$\overline{\mathrm{D}(\mathrm{EXR}(-2))}$ & -0.007484 & 0.019050 & -0.392875 & 0.6988 \\
\hline$\overline{\mathrm{D}(\mathrm{TBR})}$ & -0.024438 & 0.053055 & -0.460619 & 0.6503 \\
\hline$\overline{\mathrm{D}(\text { LNGFCF })}$ & -0.313385 & 0.576513 & -0.543587 & 0.5930 \\
\hline$\overline{\mathrm{D}(\mathrm{LNGFCF}(-2))}$ & 0.098202 & 0.493013 & 0.199187 & 0.8442 \\
\hline$\overline{\mathrm{ECM}(-1)}$ & 0.338156 & 0.215669 & 1.567934 & 0.1334 \\
\hline$\overline{\operatorname{RESID}(-1)}$ & -0.602101 & 0.356319 & -1.689781 & 0.1074 \\
\hline RESID(-2) & -0.527277 & 0.300411 & -1.755183 & 0.0953 \\
\hline R-squared & 0.175201 & Mean dep & dent var & $-4.75 \mathrm{E}-17$ \\
\hline Adjusted R-squared & -0.302315 & S.D. depe & ent var & 0.379331 \\
\hline S.E. of regression & 0.432889 & Akaike in & criterion & 1.447972 \\
\hline Sum squared resid & 3.560457 & Schwarz c & erion & 2.003064 \\
\hline Log likelihood & -10.44357 & Hannan-Q & nn criter. & 1.628918 \\
\hline F-statistic & 0.366901 & Durbin-W & son stat & 2.175459 \\
\hline$\overline{\operatorname{Prob}(F-\text {-statistic) }}$ & 0.954021 & & & \\
\hline
\end{tabular}


Appendix 6. Result of model stability test (CUSUM TEST)

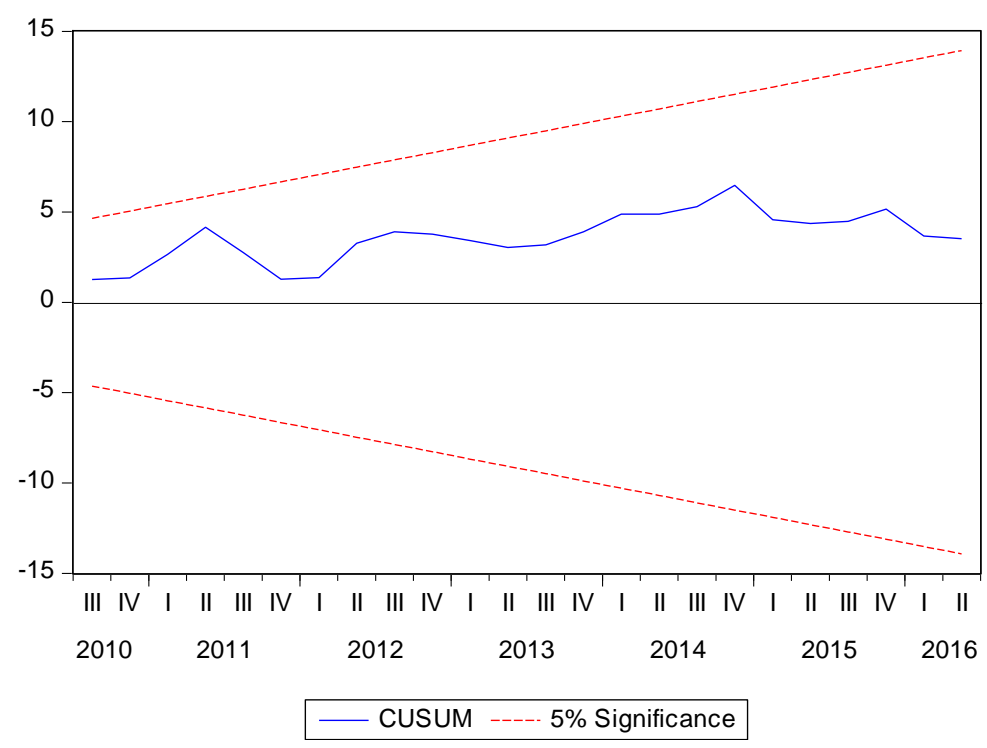

Appendix 7. Result of model stability test (CUSUM OF SQUARES TEST)

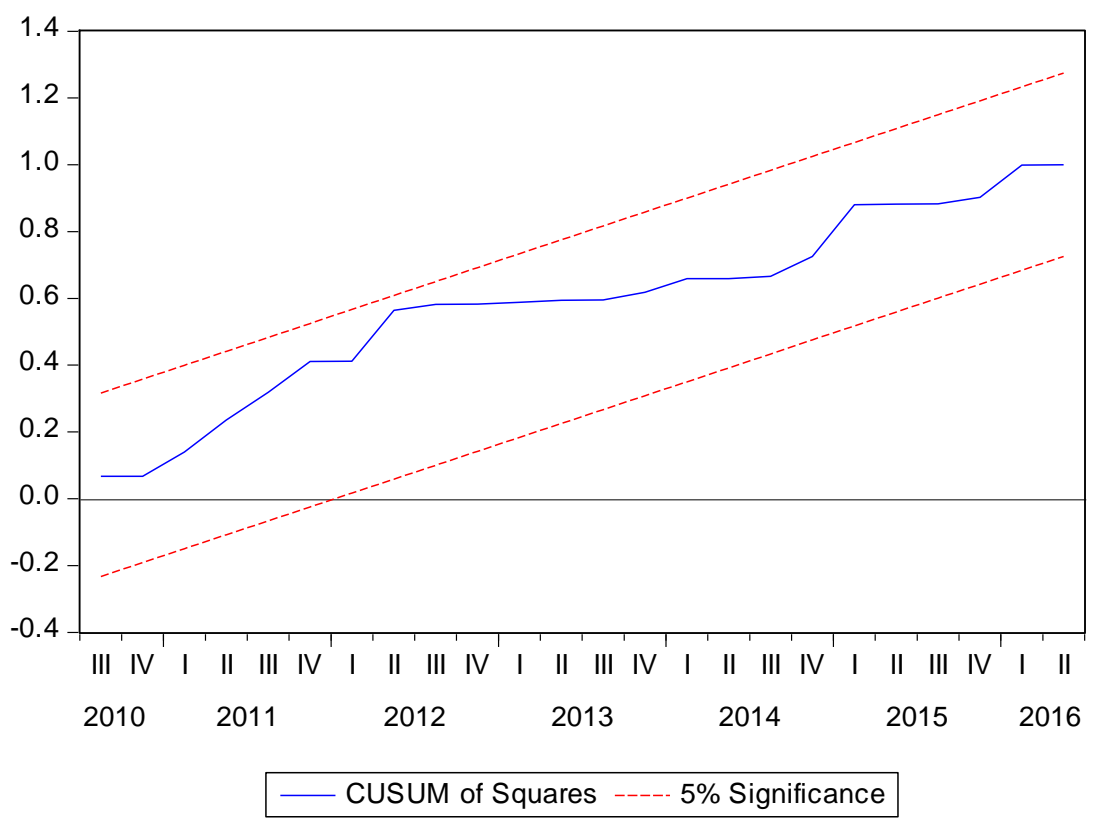

